\title{
Ascorbic Acid-The Little-Known Antioxidant in Woody Plants
}

\author{
Karolina Bilska ${ }^{1}$, Natalia Wojciechowska ${ }^{1,2}$, Shirin Alipour ${ }^{1,3}$ and Ewa Marzena Kalemba ${ }^{1, *(\mathbb{D}}$ \\ 1 Institute of Dendrology, Polish Academy of Sciences, Parkowa 5, 62-035 Kórnik, Poland; \\ mgr.karolina.bilska@gmail.com (K.B.); natalia.wojciechowska@amu.edu.pl (N.W.); \\ salipour@man.poznan.pl (S.A.) \\ 2 Department of General Botany, Institute of Experimental Biology, Faculty of Biology, Adam Mickiewicz \\ University, Uniwersytetu Poznańskiego 6, 61-614 Poznań, Poland \\ 3 Department of Forestry, Faculty of Agriculture and Natural Resources, Lorestan University, \\ Khorramabad, Iran \\ * Correspondence: kalemba@man.poznan.pl
}

Received: 20 November 2019; Accepted: 12 December 2019; Published: 14 December 2019

\begin{abstract}
Reactive oxygen species (ROS) are constantly produced by metabolically active plant cells. The concentration of ROS may determine their role, e.g., they may participate in signal transduction or cause oxidative damage to various cellular components. To ensure cellular homeostasis and minimize the negative effects of excess ROS, plant cells have evolved a complex antioxidant system, which includes ascorbic acid (AsA). AsA is a multifunctional metabolite with strong reducing properties that allows the neutralization of ROS and the reduction of molecules oxidized by ROS in cooperation with glutathione in the Foyer-Halliwell-Asada cycle. Antioxidant enzymes involved in AsA oxidation and reduction switches evolved uniquely in plants. Most experiments concerning the role of AsA have been performed on herbaceous plants. In addition to extending our understanding of this role in additional taxa, fundamental knowledge of the complex life cycle stages of woody plants, including their development and response to environmental factors, will enhance their breeding and amend their protection. Thus, the role of AsA in woody plants compared to that in nonwoody plants is the focus of this paper. The role of AsA in woody plants has been studied for nearly 20 years. Studies have demonstrated that AsA is important for the growth and development of woody plants. Substantial changes in AsA levels, as well as reduction and oxidation switches, have been reported in various physiological processes and transitions described mainly in leaves, fruits, buds, and seeds. Evidently, AsA exhibits a dual role in the photoprotection of the photosynthetic apparatus in woody plants, which are the most important scavengers of ozone. AsA is associated with proper seed production and, thus, woody plant reproduction. Similarly, an important function of AsA is described under drought, salinity, temperature, light stress, and biotic stress. This report emphasizes the involvement of AsA in the ecological advantages, such as nutrition recycling due to leaf senescence, of trees and shrubs compared to nonwoody plants.
\end{abstract}

Keywords: antioxidant system; glutathione-ascorbate cycle; reactive oxygen species; redox status; shrubs; stress; trees

\section{Introduction}

Plants are immobile organisms and are thus particularly exposed to stress factors of both biotic and abiotic origin. Biotic stressors include all pathogenic organisms, such as viruses, bacteria, and fungi [1], as well as organisms that contribute to a reduction in the photosynthetic area, such as mining insects and herbivorous animals [2]. Currently, the effects of biotic and abiotic stresses are being expanded by 
global warming, climate change, and environmental pollution [3]. The main abiotic factors that cause stress include UV radiation, high light intensity, low or high temperature, salinity, deficient or excess water, xenobiotics, and heavy metals [4]. All of the above-mentioned stress factors cause a rapid increase in reactive oxygen species (ROS) in the plant, which leads to oxidative stress [5]. The accumulation of high levels of ROS results in oxidative damage to many cellular components and macromolecules, including lipids, proteins, nucleic acids, and sugars [6]. Among ROS, hydrogen peroxide $\left(\mathrm{H}_{2} \mathrm{O}_{2}\right)$, superoxide anion radical $\left(\mathrm{O}_{2}{ }^{\bullet-}\right)$, hydroxyl radical $(\mathrm{OH} \bullet)$, and singlet oxygen $\left({ }^{1} \mathrm{O}_{2}\right)$ are produced in plant cells as an inevitable byproduct of processes that occur under physiological conditions linked to oxygen metabolism. In addition to ROS produced in mitochondria, plants must deal with ROS produced in chloroplasts and peroxisomes during photosynthesis and photorespiration. In contrast, discrete changes in ROS concentrations are linked to cellular signaling [7]. ROS promote cellular proliferation, stress acclimation, signal transduction, differentiation and development, metabolic regulation, pathogen defense, physiological cell death, and many physiological responses such as stomata closure, as well as important physiological transitions and switches [8]. For example, ROS are formed in seeds at every stage of their development, i.e., during embryo development, maturation, desiccation, imbibition, the mobilization of storage materials, and germination [9]. Thus, the dual role of ROS in seed physiology depends on their concentration. Notably, to explain this polarity, a model of the oxidative window specifying the ROS concentration range required for the initiation of germination was developed [10].

To ensure cellular homeostasis and minimize the negative effects of ROS overproduction, plant cells have developed a complex antioxidant system. The enzymatic antioxidative system includes enzymes such as superoxide dismutase (SOD; EC 1.15.1.1), catalase (CAT; EC 1.11.1.6), and glutathione reductase (GR; EC 1.6.4.2), as well as plant-specific ROS-scavenging enzymes such as ascorbate peroxidase (APX; EC 1.11.1.11), monodehydroascorbate reductase (MDHAR; EC 1.8.5.1), and dehydroascorbate reductase (DHAR; EC 1.8.5.1). The nonenzymatic antioxidant system mainly includes low-molecular-weight and water-soluble compounds such as ascorbate (Asc) and glutathione [11], as well as fat-soluble $\alpha$-tocopherol [12]. In addition, numerous polyphenols, such as kaempferol, quercetin, luteolin, myristin, and catechin, have strong antioxidant properties [13].

Ascorbic acid (AsA) and glutathione may be contemplated as the leading antioxidants and constituents of redox signaling; however, another group of biomolecules that should be mentioned in this context are polyamines (PAs), implicated in many of the AsA functions, such as nitrogen recycling and woody plant stress responses [14]. PAs are positively charged molecules protecting the cell against oxidative damage, both directly and indirectly. Directly, they function as antioxidants themselves, thus scavenging free radicals, and indirectly, they have been reported to adjust the levels of enzymatic and/or non-enzymatic antioxidants inside the plant cell. Thus, a rise in PA concentration frequently correlates with an increase in stress resistance, mostly in woody plants like grapevine. However, on the other hand, PA catabolism is one of the main suppliers of $\mathrm{H}_{2} \mathrm{O}_{2}$ to the total $\mathrm{H}_{2} \mathrm{O}_{2}$ cell content and mostly to the cell apoplast [15]. In general, the redox buffering capability of the apoplast is low, regardless of the existence of further antioxidant molecules, such as PAs and flavonoids, and mainly depends on the AsA content due to the lack of glutathione and nicotinamide adenine dinucleotide phosphate [16]. When spermidine-treated grapevine cells/tissues were incubated with AsA and/or PA oxidase potent inhibitors, no evident apoplastic $\mathrm{H}_{2} \mathrm{O}_{2}$ or its visible effects, such as stomatal closure, were detected by light/fluorescence microscopy and by scanning/transmission electron microscopy, thus revealing a significant role for PAs and related antioxidants, such as AsA, in drought and salinity resistance [17]. Polyamine homeostasis plays a dual role by both accumulating and lessening the content of $\mathrm{H}_{2} \mathrm{O}_{2}$ within the cell, thus preserving a delicate line of equilibrium among their molecular contents, conferring plant stress cross-tolerance. Since the maintenance of proper $\mathrm{H}_{2} \mathrm{O}_{2}$ contents within the woody plant cells is of extreme significance for preserving normal developmental procedures and fighting plant stress conditions, an efficient ROS scavenging mechanism by AsA, glutathione, PAs, or 
other scavenging metabolites, along with the maintenance of suitable metabolite contents, is crucial for plant sustainable growth and survival.

\section{Synthesis and Structure of AsA}

Ascorbic acid, abbreviated as AsA, AA, Asc, and $\mathrm{AscH}_{2}$, is vitamin $\mathrm{C}$, a small, 6-carbon molecule. In plants, AsA can be formed through several pathways, including D-glucose, L-galactose, uronic acid, L-gulose, and myo-inositol pathways [18]. The synthesis and accumulation of AsA are particularly sensitive to light, especially the red-to-far-red light ratio, which is directly related to the interaction between photosynthetic and respiratory electron transport chains [11]. L-ascorbic acid $\left(\mathrm{C}_{5} \mathrm{H}_{8} \mathrm{O}_{6}\right)$ is the $\gamma$-lactone of 2,3-dehydro-L-gulonic acid, known as L-threo-hex-2-enono-1,4-lactone. AsA has strong reducing properties because the moiety between its $\mathrm{C} 2$ and $\mathrm{C} 3$ carbons easily emits two protons and electrons, becoming a dehydroascorbic acid (DHA) diketone group.

\subsection{From AsA to DHA-the Oxidation Path}

A good antioxidant is defined as a nontoxic compound existing in an oxidized form, which can be easily regenerated to the reduced form by the acquisition of electrons from another molecule. Based on the transfer of electrons and protons, cellular metabolic reactions widely use AsA as an electron donor, causing AsA oxidation to DHA. The oxidation of AsA occurs gradually in the three following stages (Figure 1). The first stage of AsA oxidation is the formation of an ascorbic anion $\left(\mathrm{AH}^{-}\right)$. In the second stage, $\mathrm{AH}^{-}$is converted to ascorbic free radical $\left(\mathrm{A}^{\bullet-}\right)$. In the third stage, $\mathrm{A}^{\bullet-}$ spontaneously disproportionates, thus generating DHA [19]. DHA can be hydrolyzed to inactive 2,3-diketogulonic acid, which is further degraded to oxalic acid because a high concentration of DHA is toxic [20].

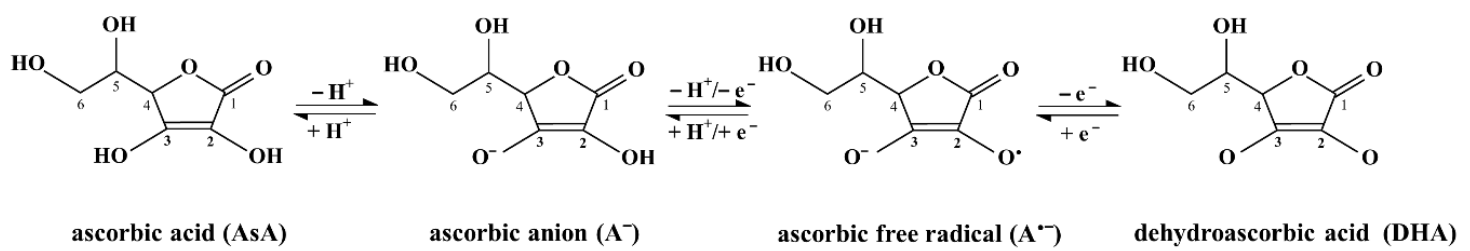

Figure 1. The transformation of ascorbic acid (AsA) into dehydroascorbic acid (DHA). The transfer of protons $\left(\mathrm{H}^{+}\right)$and electrons $\left(\mathrm{e}^{-}\right)$is indicated near the arrows. The structural formula of two intermediates, namely, ascorbic anion $\left(\mathrm{AH}^{-}\right)$and ascorbic acid radical $\left(\mathrm{A}^{\bullet-}\right)$, allow changes during three stages of oxidation. The $\gamma$-lactone-ring carbons have been numbered (C1-C6) to indicate the endiol group located between $\mathrm{C} 2$ and $\mathrm{C} 3$.

\subsection{The Continuum of AsA-DHA-AsA Switches}

The redox potential of AsA enables interactions with ${ }^{1} \mathrm{O}_{2}, \mathrm{O}_{2}{ }^{-\bullet}, \mathrm{OH} \bullet$, glutathione radicals, and tocopherol radicals [21]. AsA can directly neutralize ROS and can participate in the repair of oxidized organic molecules. Many primary and secondary metabolites can act similarly as AsA and glutathione, but unlike these compounds, AsA and glutathione interact with many components, including specific enzymes and signaling pathways [11]. Their oxidized forms are relatively stable, and their reduction is highly efficient due to enzymatic systems based on electron transporters such as nicotinamide adenine dinucleotide phosphate (NADP). The important pathway that involves both molecules is the Foyer-Halliwell-Asada pathway, also known as the ascorbate-glutathione cycle [21]. The contribution of AsA to the detoxification of $\mathrm{H}_{2} \mathrm{O}_{2}$ is based on APX activity [19], which forms MDHA (Figure 2). DHAR can regenerate DHA to AsA using reduced glutathione (GSH). Thus, cooperation between AsA and GSH is essential in cyclic redox reactions (Figure 2). Interestingly, AsA can produce intermediates with lower toxicity than glutathione radicals [22]. Thus, AsA is the best candidate reductor, which merits further study, including detailed research comparing the role of AsA in woody plants to that in nonwoody plants needed to be explained in detail. 


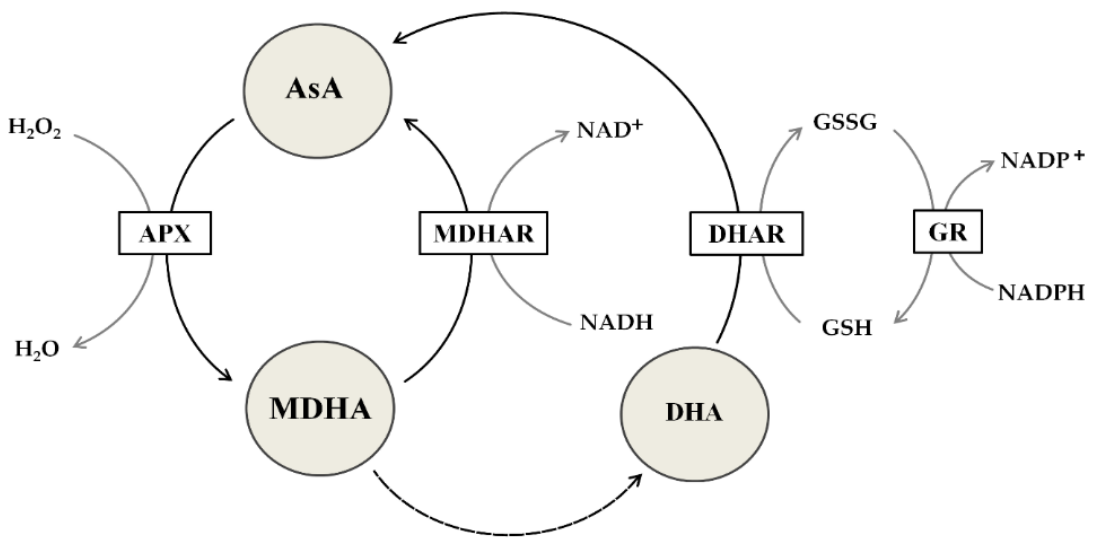

Figure 2. The ascorbate-glutathione cycle. Detoxification of hydrogen peroxide $\left(\mathrm{H}_{2} \mathrm{O}_{2}\right)$ into water $\left(\mathrm{H}_{2} \mathrm{O}\right)$ occurs due to the action of ascorbate peroxidase (APX). APX uses ascorbic acid (AsA) as an electron donor to produce monodehydroascorbate (MDHA), which is then reduced to AsA by monodehydroascorbate reductase (MDHAR), whose cofactor is nicotinamide adenine dinucleotide (NADH). Dehydroascorbate (DHA), which is formed by disproportionation, is reduced to AsA by the action of dehydroascorbate reductase (DHAR), the cofactor of which is reduced glutathione (GSH). As a result of DHAR's activity, GSH is oxidized to glutathione disulfide (GSSG), which is then reduced to GSH as a result of the activity of glutathione reductase (GR), which acquires electrons from nicotinamide adenine dinucleotide phosphate (NADPH).

\section{Functions of Ascorbate}

Asc is a cofactor for violaxanthin de-epoxidase, which is involved in photoprotection through the xanthophyll cycle, both in woody [23] and nonwoody plants [24]. As shown in a meta-analysis related to the photoprotection of plant functional groups and plant growth types, the Asc concentration of total chlorophyll (expressed in mmol of Asc per mol of chlorophyll) in nonwoody plants is not detectable, while that in woody plants can be up to 25,000 in shrubs and half that value in trees [25]. Foliar photoprotective defense systems in trees are relevant in the context of climate-originating water deficits and changes in temperature to sustain photosynthetic activity [26-28]. These photoprotective mechanisms are extremely important in the sun-exposed leaves of woody plants differing in photooxidative stress tolerance [29-31]. High levels of AsA and photoprotective pigments were reported in sun-exposed beech leaves [32], apple fruits [33], and high-light-demanding species [34], emphasizing the dual protective role of AsA in ROS scavenging and the activation of xanthophyll-cycle enzymes in leaf photoprotection. Hansen et al. [35] suggested that the accumulation of leaf pigments and antioxidant systems together might also be a prerequisite for shade tolerance with ecological implications in a mixed beech/oak forest. The three connected categories, that is, the xanthophyll cycle, photoprotection, and photooxidative stress, are overrepresented in woody plant studies.

AsA is also necessary for the anthocyanin biosynthetic pathway, the activity of enzymes involved in the biosynthesis of flavonoids and glucosinolates in plants [36], and for enzymes involved in the biosynthesis of plant hormones such as abscisic acid (ABA), gibberellins (GA), and ethylene [37,38], indicating that AsA is a multifunctional metabolite. Antioxidants are no longer considered only electron donors, as they can modulate cellular signals and gene expression. By impacting the synthesis and concentration of hormones, AsA modulates hormone-dependent signaling pathways $[39,40]$ and together with glutathione, affects redox signaling [11]. Asc alone can impact gene expression by modulating the intracellular cAMP pool [41]. APX activity-dependent AsA to DHA switches have been reported to modulate secondary cell wall-related gene expression in cotton [42]. Importantly, Asc is involved in the regulation of transcripts encoding the proteins of photosynthetic and respiratory electron transport chains [43]. Further studies are needed because the modulation of antioxidant responsive elements by AsA has been studied exclusively in humans. 


\subsection{The Involvement of Asc in the Development of Plants}

Studies concerning Arabidopsis vitamin C (vtc)-deficient mutants producing 10-30\% of wild-type Asc levels revealed that Asc regulates plant growth [44]. AsA is involved in the cell's transition from phase S to G1 [20] and the cross-linking of cell wall components [45], and is therefore important in growing tissues. It was shown that double cytosolic APX-silenced rice plants produced a semidwarf phenotype [46], whereas thylakoid APX wheat mutants exhibited decreased photosynthetic activity [47]. Both studies revealed that compensatory antioxidant mechanisms were activated in APX mutants, but deficiency in AsA to DHA switches contributed to growth abnormalities. Asc accumulates primarily in photosynthetically active tissues, meristematic tissues, flowers, young fruits, root tips, stolons, and tubers. The level of Asc depends on the developmental stage, diurnal rhythm, light, and many external factors that introduce stress [44]. Diurnal variation in the transcript levels of genes involved in AsA synthesis was reported in tomato [48] and Arabidopsis [49]. Apart from the definite involvement of Asc in the regulation of whole-plant development [50], Asc modulates the growth of woody plants in further manners.

\subsubsection{Development of Woody Plants}

The level of Asc depends on plant age. For example, the younger the mango tree, the more AsA will be in its fruits [51]. The level of Asc in leaves and fruits also differs along the vertical canopy profile. High Asc levels were detected in European beech leaves of the top and middle canopy layers, whereas the Asc level was halved in leaves of the bottom layer [52]. Fruit peels from the exterior of the canopy of three apple cultivars contained higher AsA levels than those from the interior of the canopy [53]. In nonwoody plants, the Asc distribution across canopy profiles is less studied and probably less significant. For example, DHA levels were found to differ between the second, fourth, and sixth main stem leaves of soybean, whereas no such difference was detected in AsA levels [54]. In trees, the level of Asc also depends on the needle age. Adult needles of Pinus pinaster seedlings contained several times more Asc than juvenile needles [55]. The level of the AsA-based antioxidant response is also linked to the age of trees. Turfan et al. [56] demonstrated that Anatolian black pine needles from over-500-year-old trees contained the highest concentrations of APX among all age classes of younger trees. The selection of commercial cultivars and even experimental hybrids that are extremely rich in AsA and other valuable biochemicals is a trend in crop improvement in terms of the bioavailability of human wellness compounds, such as vitamin $C[57,58]$. Natural breeding resulting in changes in the expression of bioactive molecules, such as pyrophosphate, can improve the AsA content in food products [59]. Similarly, light manipulation can elevate AsA levels. Light enhances the expression of L-galactono-1,4-lactone (GalLDH), an enzyme catalyzing the final step in the AsA biosynthesis pathway [60], which was found to be related to extremely high AsA levels in chestnut rose [61]. However genetic engineering focused on enzymes of AsA biosynthesis pathway seems to be more promising. Bulley et al. [62] suggested that the overexpression of GDP-L-galactose guanyltransferase, another enzyme involved in AsA synthesis, can contribute to significant increases in fruit AsA. Transcription factors involved in modulating the expression of genes linked to the AsA biosynthesis pathway should also be of future interest [63]. For example, a WRKY transcription factor involved in drought tolerance promotes AsA accumulation in pear [64]. Combined transcriptomic and metabolomic approaches demonstrated that Asc regulation is complex and linked with whole-plant metabolism and pathways related to stress responses [50]. In this context, vitamin C-enriched crops are a prospect for the distant future.

\subsubsection{Senescence}

Asc delays leaf senescence [65], which is an oxidative process. Thus, decreased Asc levels were reported in aged tobacco [66] and spinach leaves [67]. Barth et al. [68] demonstrated that the Arabidopsis vtc1 mutant enters senescence faster than the Arabidopsis wild-type. Recently, ROS-mediated leaf 
senescence was confirmed in APX-deficient rice mutants [69]. Many woody plant studies have shown that changes in APX activity are linked to apricot [70], ginkgo, birch [71], and beech [72] leaf senescence. Leaf senescence limits yield in certain crops, whereas in forests of deciduous trees, leaf senescence enables nutrition recycling in ecosystems.

\subsubsection{Aging}

The postharvest quality loss of nonwoody plants is followed by decreasing AsA [67]. Interestingly, in the fruit peel of tangerine $x$ sweet orange, the level of APX decreased during the postharvest aging process and increased during drought [73]. The early stages of Ginkgo biloba L. leaf expansion were accompanied by increased activity of APX [74], emphasizing the involvement of Asc in the maximization of leaf-space to increase both the interception of light and photosynthesis. Studies on photosynthetic activity in nonwoody plants frequently focus on stress conditions such as water deficits [75] or mineral element imbalances [76]. Studies on Arabidopsis vtc mutants revealed that AsA contributes to photosynthesis activity [77], but is not essential for photoprotection [78]. In contrast, Asc-related photoprotection in woody plants is well documented [27-29,32].

\subsubsection{Root development}

Asc is crucial for root growth and development. Asc stimulates the elongation of roots [79] and is involved in quiescent center (QC) organization and activity in both nonwoody and woody plants [80-82]. The maintenance of the root QC is accompanied by a low Asc content and high ascorbate oxidase (AO) activity, resulting in the dominance of DHA in the Asc pool [80]. Interestingly, studies of poplar revealed that AsA and GSH are transported from mature leaves to the root tips in a dissimilar manner. GSH is withdrawn from the phloem along the entire transport path, whereas the entire AsA pool is delivered to the root tips [83]. Interestingly, the phloem transport of AsA might be considered a shoot-to-root signal coordinating whole woody plant growth and development [83], because, in nonwoody plants, the downstream phloem transport of AsA depends strictly on the AsA content in leaves [84].

\subsubsection{Fruit Development}

Fruit development and maturation is considered to be an oxidative phenomenon, and the extent of oxidative stress depends on the action of antioxidants, i.e., AsA. Santos et al. [85] determined that APX was involved in increasing ROS removal in coffee fruits from trees grown at high altitudes. The MDHAR transcript was reported in overripe acerola (Malpighia glabra) fruits, whereas the expression of DHAR was the highest in the intermediate stage of acerola fruit ripening [86]. Fruits in particular contain large amounts of Asc, which is the best source of vitamin C for animals. Tree transcriptome sequencing revealed that the expression of genes involved in the L-galactose pathway is linked to high Asc levels in acerola fruit [87]. Large-sized mandarin fruits contain high AsA levels [88], whereas fruit color and fruit size had no detected effect on the Asc content in sweet cherry fruits [89]. Among fruits, berries are extremely rich in Asc. Sea buckthorn berries are known as the "king of vitamin C" because the AsA synthesis pathway is enriched in this species, with the uronic acid pathway characteristic to animals [90]. Aronia berries contain $31.85 \mathrm{mg}$ of Asc per $100 \mathrm{~g}$ of fresh fruits [91], whereas camu-camu berries contain up to $38 \mathrm{~g}$ of AsA per $100 \mathrm{~g}$ of dry pulp [92]. Brazilian native fruits contain $9.351 \mathrm{mg}$ AsA per $100 \mathrm{~g}$ of butia, with approximately $0.1 \mathrm{mg}$ AsA in Araça and pitanga [93]. The level of Asc (mg/100 g of fresh fruit) ranges from 85.9 to 104.5 in guava, 17.5 to 23.6 in mango, and 79.2 to 82.2 in papaya [94]. The levels of synthesized and recycled AsA in leaves and fruits are modified by light. For example, light affected the AsA levels in the apple peel and leaf but not in the apple flesh [95]. Pear fruits grown in the dark contained lower Asc levels than fruits grown in the light [96]. Similarly, AsA accumulated in the peel of shaded fruit [97]. Interestingly, tomato fruit shading directly reduced the Asc, AsA, and DHA contents, whereas tomato leaf shading increased the DHA content but had no effect on AsA [98]. Molina-Delgado et al. [99] demonstrated that on-tree apple ripening is linked to 
endogenous levels of Asc and CAT, which emphasize apple maturity patterns exhibited in orchards. In fruits located near the photooxidatively stressed leaves of orange trees, the activity of antioxidants, including APX and MDHAR, was significantly elevated [100], indicating more efficient ROS removal. Low night temperatures, water stress, and the application of nitrogen fertilizer during growth decrease Asc levels, whereas a high light intensity and fruit acidity increase Asc levels in fruits [101]. Asc accumulation is also induced by light in fruits of nonwoody plants [102]. The higher the expression of genes involved in AsA biosynthesis, the higher the AsA content in developing pepper [103], tomato fruits [104], and grape berries [105], and during fruit ripening [105,106]. Oxidative stress is alleviated by the action of antioxidant enzymes such as APX. A 3-4-fold increase of APX transcripts was found during pepper fruit ripening [107]. However, the fruit aging process results in a decrease in APX activity [108]. Additionally, Asc is involved in fruit softening [109].

\subsubsection{Bud Development}

Asc participates in the regulation of bud development. APX activity was found to be related to the transition from endodormancy to ecodormancy in Japanese pear buds [110]. As a consequence of $\mathrm{H}_{2} \mathrm{O}_{2}$ production during flower bud development, APX activity was considered one of the markers of flower bud development stages in lemon [111] and Japanese pear [110]. Asc protects sweet cherry buds during para- and endodormancy phases [112]. APX is considered one of the markers for sex determination [113]. APX is a female-specific protein in tung tree flowers [114] and is male-specific in Pistacia [115]. AsA promotes pea bud growth by interacting with hormones and light [116]. High AsA levels are important for soybean floral bud initiation $[117,118]$ and anther development in cotton [119].

\subsubsection{Seed Development}

Asc is essential in seed embryogenesis and the seed filling phase $[19,120]$. The AsA concentration was much higher in embryonic axes of developing Acer platanoides L. and Acer pseudoplatanus L. seeds [120] and mature Acer saccharinum L. embryonic axes than in cotyledons [121]. A gradual decrease in the Asc pool was reported in cotyledons of developing A. platanoides [120] and Fagus sylvatica L. seeds [122]. At early stages of seed desiccation, an elevated Asc pool was detected in the embryonic axes of A. saccharinum [121]. However, desiccated seed tissue contains low amounts of Asc because of the limited water content and metabolism shutdown [11]. The regeneration of AsA from DHA is GSH-dependent and is realized by the action of DHAR, which was reported as important to $A$. saccharinum seed viability [123]. The accumulation of Asc in fruits affects seed viability, the germination capacity, and seedling establishment, thus strongly impacting woody plant reproduction [19]. Asc also affects seed development in nonwoody plants at many stages. For example, Asc was found to be important for wheat kernel maturation [124] and ABA-dependent barley seed germination [125]. APX activity was shown to be important in soybean during the seed filling phase [126] and in rice seed germination and seedling establishment [127]. AsA was shown to be a major ROS detoxifying antioxidant during the accelerated aging of sunflower seeds [128] and cotton seeds [129], during lupine seedling growth [130], during pine hypocotyl aging, and in the pine hypocotyl axis [131]. The above data suggest that Asc acts as an important antioxidant in seed production in all plant organisms. Seed development and maturation can last up to 5-6 months in woody plants; therefore, antioxidant protection is essential. Thus, by regulating the redox status in seeds, AsA contributes to the reproduction of woody plants.

\subsection{The Involvement of Asc in Response to Abiotic Stress}

The efficient neutralization of $\mathrm{H}_{2} \mathrm{O}_{2}$ relies on fast AsA oxidation and the action of APX. APX isoforms are localized in the cytoplasm, peroxisomes, and chloroplasts. The increased stability of chloroplastic APX compared to cytosolic APX (cAPX) results from a unique loop in the enzyme structure of chloroplastic APX [132]. However, analyses of Arabidopsis mutants lacking cAPX demonstrated that the chloroplastic $\mathrm{H}_{2} \mathrm{O}_{2}$-scavenging system completely failed without cAPX [133], 
showing the interrelationship of APX isoenzymes in diminishing oxidative stress. The activity of APX was demonstrated to be important in plant responses to salt, heat, cold, light, drought, and oxidative stress [134]. Asc is an important antioxidant in the acclimation process to high light [135,136]. Arabidopsis studies revealed that an increased Asc content can limit the deleterious effects of high lightand high temperature-induced oxidative stress [137]. AsA alleviates heat stress-induced damage in tall fescue [138] and strawberry [139]. The inducible expression and activity of APX isoforms differed in sand pear cultivars exposed to heat stress, reflecting their tolerant and sensitive attributes [140]. Jin et al. [141] reported that a heat-induced increase in the APX activity in the leaves of Euonymus japonicus seedlings coincided with cyclic electron transport around photosystem I. AsA to DHA transformation protects against stress conditions in both woody and nonwoody plants.

\subsubsection{Ozone}

Ozone $\left(\mathrm{O}_{3}\right)$ is a toxic gas and powerful oxidation agent encountered by plants. The $30-50 \mathrm{ppb}$ $\mathrm{O}_{3}$ concentration significantly reduces plant biomass production and reproduction [142]. Crowther et al. [143] estimated that there are more than 3.04 trillion trees on Earth. In this context, trees might be considered important scavengers of harmful atmospheric trace gases, mainly $\mathrm{O}_{3}$, in a process that robustly involves Asc. For example, the level of apoplastic Asc in Scots Pine needles was strongly correlated with the level of atmospheric $\mathrm{O}_{3}$ during the seasonal course [34]. Additionally, the premonsoon and postmonsoon seasons, as well as air pollution, were reported to affect the level of AsA in several tree species and led to the identification of air pollution-tolerant tree species [144]. The AsA content increased in the leaves of many herbaceous plants, including crops, growing at polluted sites [145-147]. However, deciduous woody plants and conifers were more tolerant to $\mathrm{O}_{3}$ than herbaceous crops [148]. Although AsA levels shape the baseline of plant stress responses, knowledge concerning the involvement of AA in plant recovery after $\mathrm{O}_{3}$ stress has yet to be elucidated [149]. Elevated Asc levels and enhanced AsA oxidation were also reported in $\mathrm{O}_{3}$-exposed date palm seedlings [150]. Along with Asc, glutathione plays an essential role in the growth and antioxidant defense of poplar saplings under $\mathrm{O}_{3}$ conditions [151]. APX activity and AsA regeneration by MDHAR were indicated as the main determinants of $\mathrm{O}_{3}$ tolerance in Euramerican poplar, as they efficiently detoxified ROS in leaves and enabled photosynthesis [152]. Hypersensitivity to $\mathrm{O}_{3}$ was detected in the Arabidopsis mutant vtc1, which contains low Asc concentrations [68]. Nonwoody plants exposed to $\mathrm{O}_{3}$ exhibit leaf damage, decreased rates of $\mathrm{CO}_{2}$ assimilation, and a decline in photosynthesis [153], which affect crop biomass. Thus, the selection of crop cultivars [154] and varieties [155] resistant to elevated $\mathrm{O}_{3}$ levels is needed. However, the involvement of nonwoody plants in reducing air pollution and $\mathrm{O}_{3}$ scavenging is low because the world's forests absorb a third of global pollutant gas emissions every year. Furthermore, Matyssek et al. [156] reported clear interactions between $\mathrm{O}_{3}$ and drought in forest trees. $\mathrm{O}_{3}$ levels affecting stomatal function decrease drought tolerance. In contrast, a drought period followed by $\mathrm{O}_{3}$ stress may harden forest trees the impacts of $\mathrm{O}_{3}$, resulting in important ecological adaptation. Such a phenomenon is not possible in annual plants.

\subsubsection{Drought}

Water shortage causes the overproduction of ROS and oxidative stress in plants. Studies concerning monsoon seasons revealed that recovery from water stress mimicking the dry season in rice depends on antioxidants, mainly the ascorbate-glutathione cycle [157]. Drought stress applied to mature Aleppo pine trees induced the downregulation of transcripts linked to photosynthesis and ROS removal via the ascorbate-glutathione cycle and the upregulation of ROS removal via AsA-independent thiol-mediated pathways [158]. Drought stress inhibited the biosynthesis and decreased the concentration of AsA in soybean plants [159]. In response to the application of identical stress conditions, including drought, air warming, and soil with different $\mathrm{pH}$ levels, the leaves of three oak species had different antioxidant response levels. The highest Asc and AsA levels were reported in the leaves of Quercus robur seedlings, while Quercus pubescens was characterized by lower levels of total foliar Asc [160]. Interspecies 
differences in the levels of Asc forms were also detected in Acer seeds [120]. In regions characterized by dry periods, trees suffer from climate-originated oxidative stress, and the range of antioxidant responses of the ascorbate-glutathione cycle is species-specific [161]. Provenance-specific reactions to drought stress based on the synthesis of osmolytes and increasing levels of ROS scavengers, including AsA, were observed in Douglas fir [162]. The activities of APX, MDHAR, and DHAR increased as drought stress progressed in the leaves of wild almond, whereas rewatering downregulated their activity [33]. The cAPX transgene from pea enhanced water stress tolerance in transgenic plums [163]. This is a promising result because water shortages are a worldwide problem under global climate change. In general, APX activity increases in drought-tolerant tissues and species. In European larch seedlings, the APX activity was doubled under water stress and nearly 4 times higher under salinity stress. Nonwoody plant studies revealed that APX protects organelles against wounding-originated oxidative damage [164], limits salt stress-induced damage [165], and enhances resistance to chilling stress [166]. Arabidopsis vtc1 mutants exhibit increased sensitivity to salt stress [167]. Under salinity stress, multiple antioxidants, including APX, are elevated [168]. For example, DHAR overexpression enhances salt tolerance in tobacco [169]. Salinity reduces the AsA level in the roots and leaves of pistachio [170], emphasizing that AsA is involved in the response to external osmotic pressure around the roots in the soil, as well as the response to the toxic effect of salt ions accumulating mainly in leaves. AsA synthesis in roots regulates the response to salt stress by elevating ROS scavenging [171]. Many areas in the world are affected by excess salinity, but in contrast to crops, little progress has been made in improving the salt tolerance of forest tree species.

\subsubsection{Pollution}

Adaptations to metal-originated oxidative stress, including increased ascorbate-glutathione cycle activity immediately after the introduction of stress conditions, is essential for potential plant-origin bioaccumulators. In a heavy-metal-polluted environment, the use of a specific effluent can lead to the identification of different tree species that are adequate for phytoremediation [172]. The Asc level was suggested as an indicator of the environmental pollution degree after elevated Asc levels were observed in pine needles collected from stands affected by industrial pollution [173]. The air pollution tolerance index (APTI) calculated using the AsA content has been used to select plants that can be used for biomonitoring air pollution [146]. As a reaction to oxidative stress, increased APX activity was found in the roots of acacia seedlings growing in oil-contaminated soils [174] and the leaves of osier grown on Cr-rich tannery waste [175]. Moreover, studies concerning European beech leaves and Norway spruce needles revealed that the mechanisms of phytogenic reduction and the emission of mercury in grass plants and trees are similar and depend on the AsA concentration [176,177]; however, in the context of their leaf biomass, trees are clearly more efficient emitters than grass plants [177].

\subsubsection{Cold}

Studies of eight clones of Hevea brasiliensis Muell. Arg. revealed that photosystem II is extremely sensitive to cold and that ROS elimination is a crucial step for determining chilling tolerance. Strong APX, DHAR, and MDHAR activities during recovery are characteristic of cold-tolerant clones [178]. For example, the levels of Asc and other antioxidants were higher in cold-tolerant rubber tree clones than in cold-sensitive clones in response to applied cold stress [179]. Cold and salt stress upregulated the transcription and increased the activity of MDHAR and DHAR in acerola leaves [86]. Seasonal changes in the Asc level, which was highest in the winter and lowest in the summer, were detected in each needle class of Pinus sylvestris L. [180]. Asc was up to 50-fold more abundant than other antioxidants, including glutathione, tocopherol, and carotenoids, playing a key role in Quercus ilex $\mathrm{L}$. protection against photooxidative stress during winter [181]. Similar to Asc, the xanthophyll cycle also exhibits a photoprotective role during the cold acclimation of needles in winter [182], thus advantaging evergreen shrubs and trees. 


\subsubsection{Acid Rain}

Another environmental factor harmful to woody plants is acid rain, which exposes trees to toxic substances that are gradually released from the soil. Acid rain impacts seed germination, seedling growth, and photosynthesis in forest tree species [183]. Interestingly, seedlings of acid rain-sensitive and tolerant tree species exhibit modified APX expression [184], indicating that AsA action differentiates these two phenotypes. Because of the negative effect of acid rain on crop performance, simulated acid rain studies also concern nonwoody plants. For example, the lower the $\mathrm{pH}$, the higher the decrease in the AsA content observed in peppermint leaves [185]. Finally, a study investigating the combined effects of AsA application and simulated acid rain on Persian maple revealed that elevated APX activity is crucial in plant defenses against acid rain stress [186]. Considering that AsA oxidation is essential to alleviate acid rain effects and that the AsA pool is higher in trees and shrubs than in nonwoody plants, woody plants seem to be better protected against acid rain.

\subsection{The Involvement of Asc in the Response to Biotic Stress}

Asc acts in bacterial, viral, and fungal infections affecting woody plants. The Asc level differed in the roots and leaves of Eucalyptus seedlings at several stages of infection with soil-borne water mold Phytophthora cinnamomi [187]. Studies concerning the fungal disease of citrus trees caused by Phoma tracheiphila (Petri) Kantschaveli and Gikashvili revealed that APX activity was up- and downregulated depending on the type of rootstock in resistant and susceptible species, respectively [188]. Viral infection of apricot seeds resulted in decreased activity of enzymes of the ascorbate-glutathione cycle and decreased germination capacity [174]. APX was involved in different antioxidant responses to bacterial infection in young and old leaves of Pyrus communis cv. Conference [189]. AsA participated in the dynamic antioxidant response of Norway spruce phloem attacked by Ips typographus L. [190]. Thus, decreasing the availability of AsA by AO activity might be a defense strategy in poplar against leaf-chewing insects [191]. In contrast, the AsA content increased in cabbage leaves after flea beetle attack [192], indicating differences between the insect attack responses in woody and nonwoody plants. Arabidopsis vtc1 mutants were more susceptible than the Arabidopsis wild-type to viral infection [193]. Interestingly, vtc1 and vtc2 mutants exhibited enhanced resistance against bacterial infections by Alternaria brassicicola [194]. However, fungal infection resulted in declining Asc and the extensive oxidation of the remaining AsA, particularly in these mutants [195], indicating the complexity of the defense response.

\section{Mycorrhiza}

Studies of Robinia pseudoacacia revealed that ROS removal by antioxidants such as APX is additionally enhanced by the presence of arbuscular mycorrhizal fungi symbiosis [74]. Increased APX activity was also observed in tobacco seedlings inoculated with arbuscular mycorrhizal fungi [196] and tomato seedlings under salt stress [197]. APX activity is directly linked to the enhanced growth of shrub seedlings inoculated with mycorrhiza [198] and their drought tolerance [199]. Arbuscular mycorrhiza, which increases plant defenses and disease resistance, is applied as biostimulant to some agricultural and horticultural crops produced at a large scale, and is predominantly used in forest tree nurseries [200]. However, the advantages of arbuscular mycorrhiza are greatest for woody plants in natural environments and result in significant ecological services.

\subsection{The Effects of AsA Application}

Exogenously applied reducing agents strongly affect redox status and viability in oxidative environments [123]. The treatment of pruned stems of incense tree with AsA greatly reduced the $\mathrm{H}_{2} \mathrm{O}_{2}$ postwounding signal, and its effects manifested in a reduced number of vessel occlusions and a lower amount of synthesized sesquiterpenes [201]. AsA displays metal-ligand binding properties. AsA renders titanium (IV) stable in aqueous solution, resulting in the bioactive form of Ti (IV) used to 
increase crop yields [202]. Under limited micronutrient uptake, foliar Ti-ascorbate sprays improved the vigor, nutritional status, and level of Ti in the leaves of maiden apple trees [203]. AsA foliar applications contributed to increases in the primary root length and height of almond seedlings [204]. Depending on the AsA concentration used, foliar applications of AsA resulted in increases in the leaf area, shoot number, total chlorophyll content, and root dry weight of olive transplants [205]. It was suggested that foliar applications of AsA could be used as a management practice to alleviate the water stress in young peach trees and improve their performance after rewatering [206]. In nonwoody plants, AsA foliar spraying efficiently mitigated the detrimental effects of water stress in maize [207] and wheat [208], and Pb toxicity-induced oxidative damage in wheat plants [209] and faba bean [210]. Asc foliar spraying increased tolerance to water deficit by reducing ROS levels and ROS-induced damage in pot marigold [211], increasing the resistance to salt stress and lipid peroxidation in tomato [212], and affecting millet growth and salinity resistance [213]. Foliar application of AsA could be useful in crop production after the transfer of increased grain yield from small-scale laboratory experiments to large-scale production, because the combination of AsA spraying and nitrogen fertilization is beneficial for grain yield and plant height [214].

In summary, the role of AsA in woody plants to that in nonwoody plants is compared and contrasted in Table 1.

Table 1. Comparison of the involvement of different forms of ascorbate and enzymes linked to ascorbate metabolism in the regulation of plant growth and development, as well as responses to abiotic and biotic stress, between woody and nonwoody plants.

\begin{tabular}{|c|c|c|}
\hline & Woody Plants & Nonwoody Plants \\
\hline \multicolumn{3}{|l|}{ Plant Development } \\
\hline synthesis of hormones and flavonoids & [26] & {$[25,38]$} \\
\hline cellular signals & [41] & {$[40,42]$} \\
\hline whole plant growth and development & [83] & {$[19,50]$} \\
\hline vertical canopy profile & {$[52,54]$} & [62] \\
\hline leaf expansion & [74] & \\
\hline leaf senescence & [69-71] & [72] \\
\hline photosynthetic activity & [30] & {$[75,76]$} \\
\hline photoprotection & {$[23,29,32]$} & [27] \\
\hline xanthophyll cycle & {$[23,28,29]$} & [24] \\
\hline root growth & [83] & [79] \\
\hline root quiescent center organization & [82] & {$[80,81]$} \\
\hline organ and plant age & {$[63,64]$} & [66] \\
\hline fruit development & {$[51,87,95-97]$} & {$[50,102,103]$} \\
\hline fruit ripening & {$[86,99,105]$} & {$[53,60,106]$} \\
\hline fruit size & {$[88,89]$} & {$[55,56,107]$} \\
\hline Asc accumulation in fruits & [90-94] & {$[58,59,104]$} \\
\hline fruit softening and postharvest fruit aging & {$[51,73,87]$} & {$[67,108,109]$} \\
\hline cross-linking of cell wall & {$[45,131]$} & {$[79,130]$} \\
\hline bud development and dormancy & {$[110,112]$} & {$[116,117,125]$} \\
\hline flower development and sex determination & {$[111,114,115]$} & {$[113,118,119]$} \\
\hline seed embryogenesis, seed filling phase & {$[120,122]$} & {$[19,124,126]$} \\
\hline seed desiccation & [120-122] & [19] \\
\hline seed viability & [123] & {$[128,129]$} \\
\hline germination and seedling establishment & [121] & {$[127,130]$} \\
\hline diurnal rhythm & [44] & {$[48,49,84]$} \\
\hline seasonal changes & {$[32,180]$} & \\
\hline monsoon seasons & [144] & [157] \\
\hline \multicolumn{3}{|l|}{ Abiotic Stress } \\
\hline ozone & {$[34,142,150-152,156]$} & {$[153,154]$} \\
\hline oxidative stress & {$[120,123,142,159-162]$} & {$[46,137,164,210,211]$} \\
\hline
\end{tabular}


Table 1. Cont.

\begin{tabular}{lcc}
\hline & Woody Plants & Nonwoody Plants \\
\hline photooxidative stress & {$[31,34,100,181]$} & {$[47,136,164]$} \\
drought stress & {$[33,61,163,168]$} & {$[159,212]$} \\
salinity stress & {$[168,170]$} & {$[165,171,213,214]$} \\
heat stress & {$[140,141]$} & {$[19,138,139]$} \\
cold tolerance/chilling stress & {$[86,178,179,182]$} & {$[165,166,169]$} \\
light stress & {$[33-36]$} & {$[77,78,135]$} \\
shade tolerance & {$[37,96]$} & {$[98]$} \\
acid rain impact & {$[183,184]$} & {$[185]$} \\
air pollution & {$[144,173]$} & {$[145,146]$} \\
soil pollution & {$[174,175,177]$} & {$[147,176]$} \\
Biotic Stress & & \\
fungal infection and disease & {$[187,188]$} & {$[195]$} \\
viral infection & {$[174]$} & {$[193]$} \\
bacterial infection & {$[189]$} & {$[192]$} \\
insects attack & {$[190,191]$} & {$[196,197]$} \\
mycorrhiza & {$[198,199]$} & \\
Foliar Application & & {$[209]$} \\
wounding & {$[201]$} & {$[139,204,208]$} \\
increased crop yields & {$[202]$} & {$[209,212-214]$} \\
vigor and nutritional status & {$[203]$} & \\
plant growth & {$[205,206]$} & {$[207]$} \\
stress conditions & & \\
\hline & & \\
\hline
\end{tabular}

\section{Conclusions}

The antioxidant capacity of AsA is based on the detoxification of $\mathrm{H}_{2} \mathrm{O}_{2}$ and is performed by the APX enzyme and MDHAR and DHAR activities, which regenerate DHA to AsA. AsA is involved in the alleviation of oxidative stress manifested by a rapid increase in ROS following specific developmental events and multiple stress-introducing environmental factors. Recent studies have demonstrated that AsA is involved in root, shoot, leaf, and fruit development in woody plants. In particular, AsA participates in photosystem protection and acts in leaves, enabling the continuation of photosynthesis. Equally, AsA contributes to seed viability and the reproduction of trees. Some studies suggest that Asc can be used for the assessment of photooxidative stress tolerance in trees. Admittedly, AsA is crucial in redox homeostasis, and it has been suggested that its content in trees indicates the degree of environmental pollution, and it is an important player in $\mathrm{O}_{3}$ scavenging by trees, which seems to be globally important because $\mathrm{O}_{3}$ reduces the plant biomass throughout the whole ecosystem. Many studies have confirmed that, in trees subjected to drought, salinity, heat, cold, and high light intensity, as well as in trees infected by bacteria, viruses, fungi, or insects, the changed redox state can be efficiently restored to homeostasis by the action of AsA and enzymes, enabling DHA reduction. All of the above benefits in tree growth and protection have caused foliar applications of AsA to be used as a management practice in forest nurseries.

Author Contributions: Conceptualization, K.B. and E.M.K.; writing-original draft preparation, K.B., N.W., S.A., and E.M.K.; writing-review and editing, K.B., N.W., S.A., and E.M.K.; visualization, K.B. and E.M.K.; supervision, E.M.K.; project administration, E.M.K.; funding acquisition, E.M.K. All authors have read and agreed to the published version of the manuscript.

Funding: This research was funded by the National Science Center (Poland), grant No. 2015/18/E/NZ9/00729.

Acknowledgments: The authors would like to thank the Anonymous Reviewers for valuable suggestions, especially the Reviewer who contributed to the manuscript improvement in the topic related to polyamines.

Conflicts of Interest: The authors declare no conflicts of interest. 


\section{References}

1. Verma, V.; Ravindran, P.; Kumar, PP. Plant hormone-mediated regulation of stress responses. BMC Plant Biol. 2016, 16, 86. [CrossRef] [PubMed]

2. Mithöfer, A.; Schulze, B.; Boland, W. Biotic and heavy metal stress response in plants: Evidence for common signals. FEBS Lett. 2004, 566, 1-5. [CrossRef] [PubMed]

3. Nejat, N.; Mantri, N. Plant Immune System: Crosstalk Between Responses to Biotic and Abiotic Stresses the Missing Link in Understanding Plant Defence. Curr. Issues Mol. Biol. 2017, 23, 1-16. [CrossRef] [PubMed]

4. Bechtold, U.; Field, B. Molecular mechanisms controlling plant growth during abiotic stress. J. Exp. Bot. 2018, 69, 2753-2758. [CrossRef]

5. Chan, Z.; Yokawa, K.; Kim, W.Y.; Song, C.P. Editorial: ROS Regulation during Plant Abiotic Stress Responses. Front. Plant Sci. 2016, 7, 1536. [CrossRef]

6. Blokhina, O.; Virolainen, E.; Fagerstedt, K.V. Antioxidants, oxidative damage and oxygen deprivation stress: A review. Ann. Bot. 2003, 91, 179-194. [CrossRef]

7. Noctor, G.; Reichheld, J.P.; Foyer, C.H. ROS-related redox regulation and signaling in plants. Semin. Cell Dev. Biol. 2018, 80, 3-12. [CrossRef]

8. Mittler, R. ROS Are Good. Trends Plant Sci. 2017, 22, 11-19. [CrossRef]

9. Bailly, C. The signalling role of ROS in the regulation of seed germination and dormancy. Biochem. J. 2019, 476, 3019-3032. [CrossRef]

10. Bailly, C.; El-Maarouf-Bouteau, H.; Corbineau, F. From intracellular signaling networks to cell death: The dual role of reactive oxygen species in seed physiology. C. R. Biol. 2008, 331, 806-814. [CrossRef]

11. Foyer, C.H.; Noctor, G. Ascorbate and glutathione: The heart of the redox Hub. Plant Physiol. 2011, 155, 2-18. [CrossRef] [PubMed]

12. Munné-Bosch, S. Alpha-tocopherol: A multifaceted molecule in plants. Vitam. Horm. 2007, 76, 375-392. [CrossRef]

13. Theriault, M.; Caillet, S.; Kermasha, S.; Lacroix, M. Antioxidant, antiradical and antimutagenic activities of phenolic compounds present in maple products. Food Chem. 2006, 98, 490-501. [CrossRef]

14. Paschalidis, K.; Moschou, P.N.; Aziz, A.; Toumi, I.; Roubelakis-Angelakis, K.A. Polyamines in Grapevine: An Update. In Grapevine Molecular Physiology E Biotechnology; Roubelakis-Angelakis, K.A., Ed.; Springer: Dordrecht, The Netherlands, 2009; pp. 207-228. [CrossRef]

15. Gupta, K.; Sengupta, A.; Chakraborty, M.; Gupta, B. Hydrogen Peroxide and Polyamines Act as Double Edged Swords in Plant Abiotic Stress Responses. Front. Plant Sci. 2019, 7, 1343. [CrossRef]

16. Akram, N.A.; Shafiq, F.; Ashraf, M. Ascorbic Acid-A Potential Oxidant Scavenger and Its Role in Plant Development and Abiotic Stress Tolerance. Front. Plant Sci. 2017, 8, 613. [CrossRef]

17. Paschalidis, K.; Toumi, I.; Moschou, P.N.; Roubelakis-Angelakis, K.A. ABA-dependent amine oxidases-derived $\mathrm{H}_{2} \mathrm{O}_{2}$ affects stomata conductance. Plant Signal. Behav. 2010, 5, 1153-1156. [CrossRef]

18. Wang, J.; Zhang, Z.; Huang, R. Regulation of ascorbic acid synthesis in plants. Plant Signal. Behav. 2013, 8, e24536. [CrossRef]

19. Arrigoni, O.; De Gara, L.; Tommasi, F.; Liso, R. Changes in the ascorbate system during seed development of Vicia faba L. Plant Physiol. 1992, 99, 235-238. [CrossRef]

20. Arrigoni, O. Ascorbate System in Plant Development. J. Bioenerg. Biomembr. 1994, 26, 407-419. [CrossRef]

21. Noctor, G.; Foyer, C.H. Ascorbate and glutathione: Keeping active oxygen under control. Ann. Rev. Plant Physiol. Plant Mol. Biol. 1998, 49, 249-279. [CrossRef]

22. Sturgeon, B.E.; Sipe, H.J., Jr.; Barr, D.P.; Corbett, J.T.; Martinez, J.G.; Mason, R.P. The fate of the oxidizing tyrosyl radical in the presence of glutathione and ascorbate. Implications for the radical sink hypothesis. J. Biol. Chem. 1998, 273, 30116-30121. [CrossRef] [PubMed]

23. Müller-Moulé, P.; Conklin, P.L.; Niyogi, K.K. Ascorbate deficiency can limit violaxanthin de-epoxidase activity in vivo. Plant Physiol. 2002, 128, 970-977. [CrossRef] [PubMed]

24. Logan, B.A.; Grace, S.C.; Adams, W.W., III; Demmig-Adams, B. Seasonal differences in xanthophyll cycle characteristics and antioxidants in Mahonia repens growing in different light environments. Oecologia 1998, 116, 9-17. [CrossRef] [PubMed] 
25. Fernández-Marín, B.; Hernández, A.; Garcia-Plazaola, J.I.; Esteban, R.; Míguez, F.; Artetxe, U.; Gómez-Sagasti, M.T. Photoprotective strategies of Mediterranean plants in relation to morphological traits and natural environmental pressure: A meta-analytical approach. Front. Plant Sci. 2017, 8, 1051. [CrossRef] [PubMed]

26. Wujeska, A.; Bossinger, G.; Tausz, M. Responses of foliar antioxidative and photoprotective defence systems of trees to drought: A meta-analysis. Tree Physiol. 2013, 33, 1018-1029. [CrossRef]

27. Ramírez-Valiente, J.A.; Koehler, K.; Cavender-Bares, J. Climatic origins predict variation in photoprotective leaf pigments in response to drought and low temperatures in live oaks (Quercus series Virentes). Tree Physiol. 2015, 35, 521-534. [CrossRef]

28. Contran, N.; Günthardt-Goerg, M.S.; Kuster, T.M.; Cerana, R.; Crosti, P.; Paoletti, E. Physiological and biochemical responses of Quercus pubescens to air warming and drought on acidic and calcareous soils. Plant Biol. 2013, 15, 157-168. [CrossRef]

29. Chaves, A.R.; Ten-Caten, A.; Pinheiro, H.A.; Ribeiro, A.; DaMatta, F.M. Seasonal changes in photoprotective mechanisms of leaves from shaded and unshaded field-grown coffee (Coffea arabica L.) trees. Trees 2008, 22, 351. [CrossRef]

30. Santini, J.; Giannettini, J.; Herbette, S.; Pailly, O.; Ollitrault, P.; Luro, F.; Berti, L. Physiological and biochemical response to photooxidative stress of the fundamental citrus species. Sci. Hortic. 2012,147, 126-135. [CrossRef]

31. Sorkheh, K.; Shiran, B.; Rouhi, V.; Khodambashi, M.; Sofo, A. Regulation of the ascorbate-glutathione cycle in wild almond during drought stress. Russ. J. Plant Physiol. 2011, 58, 76-84. [CrossRef]

32. Haberer, K.; Jaeger, L.; Rennenberg, H. Seasonal patterns of ascorbate in the needles of Scots Pine (Pinus sylvestris L.) trees: Correlation analyses with atmospheric $\mathrm{O}_{3}$ and $\mathrm{NO}_{2}$ gas mixing ratios and meteorological parameters. Environ. Pollut. 2006, 139, 224-231. [CrossRef] [PubMed]

33. Ma, F.W.; Cheng, L.L. Exposure of the shaded side of apple fruit to full sun leads to up-regulation of both the xanthophyll cycle and the ascorbate-glutathione cycle. Plant Sci. 2004, 166, 1479-1486. [CrossRef]

34. Cai, Z.Q.; Slot, M.; Fan, Z.X. Leaf development and photosynthetic properties of three tropical tree species with delayed greening. Photosynthetica 2005, 43, 91-98. [CrossRef]

35. Hansen, U.; Fiedler, B.; Rank, B. Variation of pigment composition and antioxidative systems along the canopy light gradient in a mixed beech/oak forest: A comparative study on deciduous tree species differing in shade tolerance. Trees 2002, 16, 354-364. [CrossRef]

36. Page, M.; Sultana, N.; Paszkiewicz, K.; Florance, H.; Smirnoff, N. The influence of ascorbate on anthocyanin accumulation during high light acclimation in Arabidopsis thaliana: Further evidence for redox control of anthocyanin synthesis. Plant Cell Environ. 2012, 35, 388-404. [CrossRef]

37. De Tullio, C.; Arrigoni, O. The ascorbic acid system in seeds: To protect and to serve. Seed Sci. Res. 2003, 13, 249-260. [CrossRef]

38. Chen, S.Y.; Chien, C.T.; Chung, J.D.; Yang, Y.S.; Kuo, S.R. Dormancy-break and germination in seeds of Prunus campanulata (Rosaceae), role of covering layers and changes in concentration of abscisic acid and gibberellins. Seed Sci. Res. 2007, 17, 21-32. [CrossRef]

39. Arrigoni, O.; de Tullio, M.C. The role of ascorbic acid in cell metabolism: Between gene-directed functions and unpredictable chemical reactions. J. Plant Physiol. 2000, 157, 481-488. [CrossRef]

40. Pignocchi, C.; Kiddle, G.; Hernández, I.; Foster, S.J.; Asensi, A.; Taybi, T.; Barnes, J.; Foyer, C.H. Ascorbate oxidase-dependent changes in the redox state of the apoplast modulate gene transcript accumulation leading to modified hormone signaling and orchestration of defense processes in tobacco. Plant Physiol. 2006, 141, 423-435. [CrossRef]

41. Belin, S.; Kaya, F.; Burtey, S.; Fontes, M. Ascorbic Acid and gene expression: Another example of regulation of gene expression by small molecules? Curr. Genom. 2010, 11, 52-57. [CrossRef]

42. Guo, K.; Du, X.; Tu, L.; Tang, W.; Wang, P.; Wang, M.; Liu, Z.; Zhang, X. Fibre elongation requires normal redox homeostasis modulated by cytosolic ascorbate peroxidase in cotton (Gossypium hirsutum). J. Exp. Bot. 2016, 67, 3289-3301. [CrossRef] [PubMed]

43. Queval, G.; Foyer, C.H. Redox regulation of photosynthetic gene expression. Philos. Trans. R. Soc. Lond. B Biol. Sci. 2012, 367, 3475-3485. [CrossRef] [PubMed]

44. Veljović-Jovanović, S.; Vidović, M.; Morina, F. Ascorbate as a Key Player in Plant Abiotic Stress Response and Tolerance. In Ascorbic Acid in Plant Growth, Development and Stress Tolerance; Hossain, M., Munné-Bosch, S., Burritt, D., Diaz-Vivancos, P., Fujita, M., Lorence, A., Eds.; Springer: Berlin/Heidelberg, Germany, 2017. 
45. Zarra, I.; Sánchez, M.; Queijeiro, E.; Peña, M.J.; Revilla, G. The cell wall stiffening mechanism in Pinus pinaster Aiton: Regulation by apoplastic levels of ascorbate and hydrogen peroxide. J. Sci. Food Agric. 1999, 79, 416-420. [CrossRef]

46. Rosa, S.B.; Caverzan, A.; Teixeira, F.K.; Lazzarotto, F.; Silveira, J.A.G.; Ferreira-Silva, S.L.; Abreu-Neto, J.; Margis, R.; Margis-Pinheiro, M. Cytosolic APx knockdown indicates an ambiguous redox responses in rice. Phytochemistry 2010, 71, 548-558. [CrossRef]

47. Danna, C.H.; Bartoli, C.G.; Sacco, F.; Ingala, L.R.; Santa-María, G.E.; Guiamet, J.J.; Ugalde, R.A. Thylakoid-bound ascorbate peroxidase mutant exhibits impaired electron transport and photosynthetic activity. Plant Physiol. 2003, 132, 2116-2125. [CrossRef]

48. Massot, C.; Stevens, R.; Génard, M.; Longuenesse, J.J.; Gautier, H. Light affects ascorbate content and ascorbate-related gene expression in tomato leaves more than in fruits. Planta 2012, 235, 153-163. [CrossRef]

49. Laing, W.; Norling, C.; Brewster, D.; Wright, M.; Bulley, S. Ascorbate concentration in Arabidopsis thaliana and expression of ascorbate related genes using RNAseq in response to light and the diurnal cycle. bioRxiv 2017, 138008. [CrossRef]

50. Alhagdow, M.; Mounet, F.; Gilbert, L.; Nunes-Nesi, A.; Garcia, V.; Just, D.; Petit, J.; Beauvoit, B.; Fernie, A.R.; Rothan, C.; et al. Silencing of the mitochondrial ascorbate synthesizing enzyme L-galactono-1, 4-lactone dehydrogenase affects plant and fruit development in tomato. Plant Physiol. 2007, 145, 1408-1422. [CrossRef]

51. Meena, N.K.; Asrey, R. Tree age affects physicochemical, functional quality and storability of Amrapali mango (Mangifera indica L.) fruits. J. Sci. Food Agric. 2018, 98, 3255-3262. [CrossRef]

52. Scartazza, A.; Di Baccio, D.; Bertolotto, P.; Gavrichkova, O.; Matteucci, G. Investigating the European beech (Fagus sylvatica L.) leaf characteristics along the vertical canopy profile: Leaf structure, photosynthetic capacity, light energy dissipation and photoprotection mechanisms. Tree Physiol. 2016, 36, 1060-1076. [CrossRef]

53. Feng, F.; Li, M.; Ma, F.; Cheng, L. Effects of location within the tree canopy on carbohydrates, organic acids, amino acids and phenolic compounds in the fruit peel and flesh from three apple (Malus domestica) cultivars. Hortic. Res. 2014, 1, 14019. [CrossRef] [PubMed]

54. Cheng, F.Y.; Burkey, K.O.; Robinson, J.M.; Booker, F.L. Leaf extracellular ascorbate in relation to $\mathrm{O}_{3}$ tolerance of two soybean cultivars. Environ. Pollut. 2007, 150, 355-362. [CrossRef] [PubMed]

55. De Miguel, M.; Guevara, M.Á.; Sánchez-Gómez, D.; de María, N.; Díaz, L.M.; Mancha, J.A.; Fernández de Simón, B.; Cadahía, E.; Desai, N.; Aranda, I.; et al. Organ-specific metabolic responses to drought in Pinus pinaster Ait. Plant Physiol. Biochem. 2016, 102, 17-26. [CrossRef] [PubMed]

56. Turfan, N.; Alay, M.; Sariyildiz, T. Effect of tree age on chemical compounds of ancient Anatolian black pine (Pinus nigra subsp. pallasiana) needles in Northwest Turkey. iForest 2018, 11, 406-410. [CrossRef]

57. Martí, M.C.; Camejo, D.; Vallejo, F.; Romojaro, F.; Bacarizo, S.; Palma, J.M.; Sevilla, F.; Jiménez, A. Influence of fruit ripening stage and harvest period on the antioxidant content of sweet pepper cultivars. Plant Foods Hum. Nutr. 2011, 66, 416-423. [CrossRef]

58. Lester, G.E.; Crosby, K.M. Ascorbic acid, folic acid, and potassium content in postharvest green-flesh honeydew muskmelons: Influence of cultivar, fruit size, soil type, and year. J. Am. Soc. Hortic. Sci. 2002, 127, 843-847. [CrossRef]

59. Osorio, S.; Nunes-Nesi, A.; Stratmann, M.; Fernie, A. Pyrophosphate levels strongly influence ascorbate and starch content in tomato fruit. Front. Plant Sci. 2013, 4, 308. [CrossRef]

60. Pateraki, I.; Sanmartin, M.; Kalamaki, M.S.; Gerasopoulos, D.; Kanellis, A.K. Molecular characterization and expression studies during melon fruit development and ripening of L-galactono-1,4-lactone dehydrogenase. J. Exp. Bot. 2004, 55, 1623-1633. [CrossRef]

61. An, H.M.; Fan, W.G.; Chen, L.G.; Asghar, S.; Liu, Q.L. Molecular characterisation and expression of L-galactono-1, 4-lactone dehydrogenase and L-ascorbic acid accumulation during fruit development in Rosa roxburghii. J. Hort. Sci. Biotechnol. 2007, 82, 627-635. [CrossRef]

62. Bulley, S.M.; Rassam, M.; Hoser, D.; Otto, W.; Schünemann, N.; Wright, M.; MacRae, E.; Gleave, A.; Laing, W. Gene expression studies in kiwifruit and gene over-expression in Arabidopsis indicates that GDP-L-galactose guanyltransferase is a major control point of vitamin C biosynthesis. J. Exp. Bot. 2009, 60, 765-778. [CrossRef] [PubMed] 
63. Ye, J.; Hu, T.; Yang, C.; Li, H.; Yang, M.; Ijaz, R.; Ye, Z.; Zhang, Y. Transcriptome profiling of tomato fruit development reveals transcription factors associated with ascorbic acid, carotenoid and flavonoid biosynthesis. PLoS ONE 2015, 10, e0130885. [CrossRef] [PubMed]

64. Liu, Y.; Yang, T.; Lin, Z.; Gu, B.; Xing, C.; Zhao, L.; Dong, H.; Junzhi, G.; Xie, Z.; Zhang, S.; et al. WRKY transcription factor PbrWRKY53 from Pyrus betulaefolia is involved in drought tolerance and AsA accumulation. Plant Biotechnol. J. 2019, 17, 1770-1787. [CrossRef] [PubMed]

65. Garg, O.P.; Kapoor, V. Retardation of Leaf Senescence by Ascorbic Acid. J. Exp. Bot. 1972, 23, 699-703. [CrossRef]

66. Takahama, U.; Hirotsu, M.; Oniki, T. Age-dependent changes in levels of ascorbic acid and chlorogenic acid, and activities of peroxidase and superoxide dismutase in the apoplast of tobacco leaves: Mechanism of the oxidation of chlorogenic acid in the apoplast. Plant Cell Phys. 1999, 40, 716-724. [CrossRef]

67. Hodges, D.M.; Forney, C.F. Postharvest ascorbate metabolism in two cultivars of spinach differing in their senescence rates. J. Am. Soc. Hort. Sci. 2003, 128, 930-935. [CrossRef]

68. Barth, C.; Moeder, W.; Klessig, D.F.; Conklin, P.L. The timing of senescence and response to pathogens is altered in the ascorbate-deficient Arabidopsis mutant vitamin c-1. Plant Physiol. 2004, 134, 1784-1792. [CrossRef]

69. Ribeiro, C.W.; Korbes, A.P.; Garighan, J.A.; Jardim-Messeder, D.; Carvalho, F.E.L.; Sousa, R.H.V.; Caverzan, A.; Teixeira, F.K.; Silveira, J.A.G.; Margis-Pinheiro, M. Rice peroxisomal ascorbate peroxidase knockdown affects ROS signaling and triggers early leaf senescence. Plant Sci. 2017, 263, 55-65. [CrossRef]

70. Scebba, F.; Sebastiani, L.; Vitagliano, C. Activities of antioxidant enzymes during senescence of Prunus armeniaca leaves. Biol. Plant. 2001, 44, 41-46. [CrossRef]

71. Kukavica, B.; Veljovic-Jovanovic, S. Senescence-related changes in the antioxidant status of ginkgo and birch leaves during autumn yellowing. Phys. Plant. 2004, 122, 321-327. [CrossRef]

72. Kraj, W. Reactive oxygen species and antioxidant levels as the factors of autumn senescence in phenological forms of beech (Fagus sylvatica L.). Acta Phys. Plant. 2016, 38, 32. [CrossRef]

73. Lliso, I.; Tadeo, F.R.; Phinney, B.S.; Wilkerson, C.G.; Talón, M. Protein changes in the albedo of citrus fruits on postharvesting storage. J. Agric. Food Chem. 2007, 55, 9047-9053. [CrossRef] [PubMed]

74. Yang, X.S.; Chen, G.X.; Wei, X.D.; Xie, K.B. Enhanced antioxidant protection at the early stages of leaf expansion in ginkgo under natural environmental conditions. Biol. Plant. 2012, 56, 181-186. [CrossRef]

75. Sales, C.R.; Ribeiro, R.V.; Silveira, J.A.; Machado, E.C.; Martins, M.O.; Lagôa, A.M.M. Superoxide dismutase and ascorbate peroxidase improve the recovery of photosynthesis in sugarcane plants subjected to water deficit and low substrate temperature. Plant Physiol. Biochem. 2013, 73, 326-336. [CrossRef] [PubMed]

76. Landi, M.; Remorini, D.; Pardossi, A.; Guidi, L. Boron excess affects photosynthesis and antioxidant apparatus of greenhouse Cucurbita pepo and Cucumis sativus. J. Plant Res. 2013, 126, 775-786. [CrossRef] [PubMed]

77. Talla, S.; Riazunnisa, K.; Padmavathi, L.; Sunil, B.; Rajsheel, P.; Raghavendra, A.S. Ascorbic acid is a key participant during the interactions between chloroplasts and mitochondria to optimize photosynthesis and protect against photoinhibition. J. Biosci. 2011, 36, 163-173. [CrossRef]

78. Plumb, W.; Townsend, A.J.; Rasool, B.; Alomrani, S.; Razak, N.; Karpinska, B.; Ruban, A.V.; Foyer, C.H. Ascorbate-mediated regulation of growth, photoprotection, and photoinhibition in Arabidopsis thaliana. J. Exp. Bot. 2018, 69, 2823-2835. [CrossRef]

79. Cordoba-Pedregosa, M.D.C.; Gonzalez-Reyes, J.A.; Canadillas, M.D.S.; Navas, P.; Cordoba, F. Role of apoplastic and cell-wall peroxidases on the stimulation of root elongation by ascorbate. Plant Physiol. 1996, 112, 1119-1125. [CrossRef]

80. Potters, G.; Horemans, N.; Bellone, S.; Caubergs, R.J.; Trost, P.; Guisez, Y.; Asard, H. Dehydroascorbate influences the plant cell cycle through a glutathione-independent reduction mechanism. Plant Physiol. 2004, 134, 1479-1487. [CrossRef]

81. Liso, R.; De Tullio, M.C.; Ciraci, S.; Balestrini, R.; La Rocca, N.; Bruno, L.; Chiappetta, A.; Bitonti, M.B.; Bonfante, P.; Arrigoni, O. Localization of ascorbic acid, ascorbic acid oxidase, and glutathione in roots of Cucurbita maxima L. J. Exp. Bot. 2004, 55, 2589-2597. [CrossRef]

82. Jiang, K.; Feldman, L.J. Regulation of root apical meristem development. Ann. Rev. Cell Dev. Biol. 2005, 21, 485-509. [CrossRef] 
83. Herschbach, C.; Scheerer, U.; Rennenberg, H. Redox states of glutathione and ascorbate in root tips of poplar (Populus tremula $\times$ P. alba) depend on phloem transport from the shoot to the roots. J. Exp. Bot. 2010, 61, 1065-1074. [CrossRef] [PubMed]

84. Tedone, L.; Hancock, R.D.; Alberino, S.; Haupt, S.; Viola, R. Long-distance transport of L-ascorbic acid in potato. BMC Plant Biol. 2004, 4, 16. [CrossRef] [PubMed]

85. Santos, M.O.; Silveira, H.R.D.; de Souza, K.R.D.; Lima, A.A.; Boas, L.V.V.; Barbosa, B.C.F.; Barreto, H.G.; Alves, J.D.; Chalfun-Junior, A. Antioxidant System Differential Regulation is Involved in Coffee Ripening Time at Different Altitudes. Trop. Plant Biol. 2018, 11, 131-140. [CrossRef]

86. Eltelib, H.A.; Badejo, A.A.; Fujikawa, Y.; Esaka, M. Gene expression of monodehydroascorbate reductase and dehydroascorbate reductase during fruit ripening and in response to environmental stresses in acerola (Malpighia glabra). J. Plant Phys. 2011, 168, 619-627. [CrossRef] [PubMed]

87. Dos Santos, C.P.; Batista, M.C.; da Cruz Saraiva, K.D.; Roque, A.L.M.; de Souza Miranda, R.; Alexandre, E.; Silva, L.M.; Moura, C.F.H.; Alves Filho, E.G.; Canuto, K.M.; et al. Transcriptome analysis of acerola fruit ripening: Insights into ascorbate, ethylene, respiration, and softening metabolisms. Plant Mol. Biol. 2019, 101, 269-296. [CrossRef]

88. Khalid, S.; Malik, A.U.; Khan, A.S.; Shahid, M.; Shafique, M. Tree age, fruit size and storage conditions affect levels of ascorbic acid, total phenolic concentrations and total antioxidant activity of 'Kinnow' mandarin juice. J. Sci. Food Agric. 2016, 96, 1319-1325. [CrossRef]

89. Usenik, V.; Stampar, F.; Petkovsek, M.M.; Kastelec, D. The effect of fruit size and fruit colour on chemical composition in 'Kordia' sweet cherry (Prunus avium L.). J. Food Comp. Anal. 2015, 38, 121-130. [CrossRef]

90. He, C.; Zhang, G.; Zhang, J.; Zeng, Y.; Liu, J. Integrated analysis of multiomic data reveals the role of the antioxidant network in the quality of sea buckthorn berry. FASEB J. 2017, 31, 1929-1938. [CrossRef]

91. Catană, L.; Catană, M.; Iorga, E.; Asănică, A.C.; Lazăr, A.-G.; Lazăr, M.-A.; Belc, N. Vitamin c and total polyphenol content and antioxidant capacity of fresh and processed fruits of Aronia melanocarpa. Sci. Pap. Ser. B Hort. 2017, 61, 433-440.

92. Cunha-Santos, E.C.E.; Viganó, J.; Neves, D.A.; Martínez, J.; Godoy, H.T. Vitamin C in camu-camu [Myrciaria dubia (H.B.K.) McVaugh]: Evaluation of extraction and analytical methods. Food Res. Int. 2019, 115, 160-166. [CrossRef]

93. Denardin, C.C.; Hirsch, G.E.; da Rocha, R.F.; Vizzotto, M.; Henriques, A.T.; Moreira, J.C.F.; Guma, F.T.C.R.; Emanuelli, T. Antioxidant capacity and bioactive compounds of four Brazilian native fruits. J. Food Drug Anal. 2015, 23, 387-398. [CrossRef] [PubMed]

94. Oliveira Dda, S.; Lobato, A.L.; Ribeiro, S.M.; Santana, A.M.; Chaves, J.B.; Pinheiro-Sant'Ana, H.M. Carotenoids and Vitamin C during Handling and Distribution of Guava (Psidium guajava L.), Mango (Mangifera indica L.), and Papaya (Carica papaya L.) at Commercial Restaurants. J. Agric. Food Chem. 2010, 58, 6166-6172. [CrossRef] [PubMed]

95. Li, M.J.; Ma, F.W.; Shang, P.F.; Zhang, M.; Hou, C.M.; Liang, D. Influence of light on ascorbate formation and metabolism in apple fruits. Planta 2009, 230, 39-51. [CrossRef] [PubMed]

96. Hu, P.Z.; An, Q.; Kai, J.Q.; Shu, T.T.; Ju, Y.W.; Xiao, S.H.; Shao, L.Z. The effect of bagging on ascorbate in Pyrus fruit. N. Z. J. Crop Hort. Sci. 2019, 47, 19-31. [CrossRef]

97. Lado, J.; Alós, E.; Rodrigo, M.J.; Zacarías, L. Light avoidance reduces ascorbic acid accumulation in the peel of Citrus fruit. Plant Sci. 2015, 231, 138-147. [CrossRef] [PubMed]

98. Gautier, H.; Massot, C.; Stevens, R.; Sérino, S.; Génard, M. Regulation of tomato fruit ascorbate content is more highly dependent on fruit irradiance than leaf irradiance. Ann. Bot. 2009, 103, 495-504. [CrossRef] [PubMed]

99. Molina-Delgado, D.; Larrigaudiere, C.; Recasens, I. Antioxidant activity determines on-tree maturation in ‘Golden Smoothee' apples. J. Sci. Food Agric. 2009, 89, 1207-1212. [CrossRef]

100. Poiroux-Gonord, F.; Santini, J.; Fanciullino, A.L.; Lopez-Lauri, F.; Giannettini, J.; Sallanon, H.; Berti, L.; Urban, L. Metabolism in orange fruits is driven by photooxidative stress in the leaves. Phys. Plant. 2013, 149, 175-187. [CrossRef]

101. Mellidou, I.; Koukounaras, A.; Chatzopoulou, F.; Kostas, S.; Kanellis, A.K. Plant Vitamin C: One Single Molecule with a Plethora of Roles. In Fruit and Vegetable Phytochemicals: Chemistry and Human Health, 2nd ed.; Yahia, E.M., Ed.; John Wiley Sons, Ltd.: Hoboken, NJ, USA, 2017. 
102. Ntagkas, N.; Woltering, E.; Bouras, S.; de Vos, R.C.; Dieleman, J.A.; Nicole, C.C.; Labrie, C.; Marcelis, L.F. Light-Induced Vitamin C Accumulation in Tomato Fruits is Independent of Carbohydrate Availability. Plants 2019, 8, 86. [CrossRef]

103. Chiaiese, P.; Corrado, G.; Minutolo, M.; Barone, A.; Errico, A. Transcriptional Regulation of Ascorbic Acid During Fruit Ripening in Pepper (Capsicum annuum) Varieties with Low and High Antioxidants Content. Plants 2019, 8, 206. [CrossRef]

104. Zhang, Z.; Zhang, X.L.; Yang, Y.; Wei, J.H.; Meng, H.; Gao, Z.H.; Xu, Y.H. Hydrogen peroxide induces vessel occlusions and stimulates sesquiterpenes accumulation in stems of Aquilaria sinensis. Plant Growth Regul. 2014, 72, 81-87. [CrossRef]

105. Cruz-Rus, E.; Botella, M.A.; Valpuesta, V.; Gomez-Jimenez, M.C. Analysis of genes involved in L-ascorbic acid biosynthesis during growth and ripening of grape berries. J. Plant Physiol. 2010, 167, 739-748. [CrossRef] [PubMed]

106. Jimenez, A.; Creissen, G.; Kular, B.; Firmin, J.; Robinson, S.; Verhoeyen, M.; Mullineaux, P. Changes in oxidative processes and components of the antioxidant system during tomato fruit ripening. Planta 2002, 214, 751-758. [CrossRef] [PubMed]

107. Schantz, M.L.; Schreiber, H.; Guillemaut, P.; Schantz, R. Changes in ascorbate peroxidase activities during fruit ripening in Capsicum annuum. FEBS Lett. 1995, 358, 149-152. [CrossRef]

108. Liu, H.; Liang, S.; Li, Q.; Bai, Y.; Yan, Y.; Guo, J. The Effects of $\mathrm{H}_{2} \mathrm{O}_{2}$ and Tea Polyphenol Treatments on Reactive Oxygen Metabolism and Ageing in Postharvest Strawberry Fruit. J. Yunnan Agric. Univ. 2017, 3, 16.

109. Dumville, J.C.; Fry, S.C. Solubilisation of tomato fruit pectins by ascorbate: A possible non-enzymic mechanism of fruit softening. Planta 2003, 217, 951-961. [CrossRef]

110. Takemura, Y.; Kuroki, K.; Jiang, M.; Matsumoto, K.; Tamura, F. Identification of the expressed protein and the impact of change in ascorbate peroxidase activity related to endodormancy breaking in Pyrus pyrifolia. Plant Phys. Biochem. 2015, 86, 121-129. [CrossRef]

111. Kasraoui, M.F.; Duquesnoy, I.; Winterton, P.; Lamaze, T. Soluble and cell wall bound peroxidase activities are markers of flower bud development stages in lemon (Citrus limon L.). J. Appl. Bot. Food Qual. 2014, 87, 1-8. [CrossRef]

112. Baldermann, S.; Homann, T.; Neugart, S.; Chmielewski, F.M.; Götz, K.P.; Gödeke, K.; Huschek, G.; Morlock, G.E.; Rawel, H. Selected plant metabolites involved in oxidation-reduction processes during bud dormancy and ontogenetic development in sweet cherry buds (Prunus avium L.). Molecules 2018, 23, 1197. [CrossRef]

113. Khattak, J.Z.; Torp, A.M.; Andersen, S.B. A genetic linkage map of Spinacia oleracea and localization of a sex determination locus. Euphytica 2006, 148, 311-318. [CrossRef]

114. Mao, Y.; Hou, J.; Chen, X.; Ni, J.; Zhao, W.; Wu, L. Identification of potential molecular markers for flower sex determination in Vernicia fordii. J. Hort. Sci. Biotechnol. 2018, 93, 264-271. [CrossRef]

115. Chen, Y.; Bai, Q.; Ruan, F.; Su, S. Proteomic analysis of differently expressed proteins in sex differentiation phases of flower buds in monoecious Pistacia chinensis Bunge. Isr. J. Plant Sci. 2019, 66, 182-195. [CrossRef]

116. Johnnykutty, A.T.; Khudairi, A.K. Role of ascorbic acid in bud development. Physiol. Plant. 1972, 26, $285-288$. [CrossRef]

117. Bharti, S.; Garg, O.P. Changes in the ascorbic acid content of the lateral buds of soybean in relation to flower induction. Plant Cell Physiol. 1970, 11, 723-727. [CrossRef]

118. Ding, X.; Wang, X.; Li, Q.; Yu, L.; Song, Q.; Gai, J.; Yang, S. Metabolomics Studies on Cytoplasmic Male Sterility during Flower Bud Development in Soybean. Int. J. Mol. Sci. 2019, 20, 2869. [CrossRef] [PubMed]

119. Ma, J.; Wei, H.; Song, M.; Pang, C.; Liu, J.; Wang, L.; Zhang, J.; Fan, S.; Yu, S. Transcriptome profiling analysis reveals that flavonoid and ascorbate-glutathione cycle are important during anther development in Upland cotton. PLoS ONE 2012, 7, e49244. [CrossRef]

120. Pukacka, S.; Ratajczak, E. Ascorbate and glutathione metabolism during development and dessication of orthodox and recalcitrant seeds of the genus Acer. Funct. Plant Biol. 2007, 34, 601-613. [CrossRef]

121. Pukacka, S.; Ratajczak, E. Antioxidative response of ascorbate-glutathione pathway enzymes and metabolites to desiccation of recalcitrant Acer saccharinum seeds. J. Plant Physiol. 2006, 163, 1259-1266. [CrossRef]

122. Pukacka, S.; Ratajczak, E. Ascorbate and glutathione metabolism during development and desiccation of beech (Fagus sylvatica L.) seeds. Plant Growth Regul. 2010, 62, 77-83. [CrossRef] 
123. Kalemba, E.M.; Ratajczak, E. The effect of a doubled glutathione level on parameters affecting the germinability of recalcitrant Acer saccharinum seeds during drying. J. Plant Physiol. 2018, 223, 72-83. [CrossRef]

124. De Gara, L.; De Pinto, M.C.; Moliterni, V.M.; D'Egidio, M.G. Redox regulation and storage processes during maturation in kernels of Triticum durum. J. Exp. Bot. 2003, 54, 249-258. [CrossRef] [PubMed]

125. Ishibashi, Y.; Aoki, N.; Kasa, S.; Sakamoto, M.; Kai, K.; Tomokiyo, R.; Watabe, G.; Yuasa, T.; Iwaya-Inoue, M. The interrelationship between abscisic acid and reactive oxygen species plays a key role in barley seed dormancy and germination. Front. Plant Sci. 2017, 8, 275. [CrossRef] [PubMed]

126. Hajduch, M.; Ganapathy, A.; Stein, J.W.; Thelen, J.J. A systematic proteomic study of seed filling in soybean. Establishment of high-resolution two-dimensional reference maps, expression profiles, and an interactive proteome database. Plant Physiol. 2005, 137, 1397-1419. [CrossRef] [PubMed]

127. Liu, S.J.; Xu, H.H.; Wang, W.Q.; Li, N.; Wang, W.P.; Lu, Z.; Møller, I.M.; Song, S.Q. Identification of embryo proteins associated with seed germination and seedling establishment in germinating rice seeds. J. Plant Physiol. 2016, 196, 79-92. [CrossRef] [PubMed]

128. De Paula, M.; Perez-Otaola, M.; Darder, M.; Torres, M.; Frutos, G.; Martimez-Honduvilla, C.J. Function of the ascorbate-glutathione cycle in aged sunflower seeds. Physiol. Plant. 1996, 96, 543-550. [CrossRef]

129. Goel, A.; Goel, A.K.; Sheoran, I.S. Changes in oxidative stress enzymes during artificial ageing in cotton (Gossypium hirsutum L.) seeds. J. Plant Physiol. 2003, 160, 1093-1100. [CrossRef] [PubMed]

130. Arrigoni, O.; Calabrese, G.; De Gara, L.; Bitonti, M.B.; Liso, R. Correlation between changes in cell ascorbate and growth of Lupinus albus seedlings. J. Plant Physiol. 1997, 150, 302-308. [CrossRef]

131. Sánchez, M.; Queijeiro, E.; Revilla, G.; Zarra, I. Changes in ascorbic acid levels in apoplastic fluid during growth of pine hypocotyls. Effect on peroxidase activities associated with cell walls. Physiol. Plant. 1997, 101, 815-820. [CrossRef]

132. Kitajima, S.; Tomizawa, K.I.; Shigeoka, S.; Yokota, A. An inserted loop region of stromal ascorbate peroxidase is involved in its hydrogen peroxide-mediated inactivation. FEBS J. 2006, 273, 2704-2710. [CrossRef]

133. Davletova, S.; Rizhsky, L.; Liang, H.; Shengqiang, Z.; Oliver, D.J.; Coutu, J.; Shulaev, V.; Schlauch, K.; Mittler, R. Cytosolic ascorbate peroxidase 1 is a central component of the reactive oxygen gene network of Arabidopsis. Plant Cell 2005, 17, 268-281. [CrossRef]

134. Pandey, S.; Fartyal, D.; Agarwal, A.; Shukla, T.; James, D.; Kaul, T.; Negi, Y.K.; Arora, S.; Reddy, M.K. Abiotic Stress Tolerance in Plants: Myriad Roles of Ascorbate Peroxidase. Front. Plant Sci. 2017, 8, 581. [CrossRef] [PubMed]

135. Müller-Moulé, P.; Havaux, M.; Niyogi, K.K. Zeaxanthin deficiency enhances the high light sensitivity of an ascorbate-deficient mutant of Arabidopsis. Plant Physiol. 2003, 133, 748-760. [CrossRef] [PubMed]

136. Zeng, L.D.; Li, M.; Chow, W.S.; Peng, C.L. Susceptibility of an ascorbate-deficient mutant of Arabidopsis to high-light stress. Photosynthetica 2018, 56, 427. [CrossRef]

137. Wang, Z.; Xiao, Y.; Chen, W.; Tang, K.; Zhang, L. Increased vitamin C content accompanied by an enhanced recycling pathway confers oxidative stress tolerance in Arabidopsis. J. Integr. Plant Biol. 2010, 52, 400-409. [CrossRef] [PubMed]

138. Chen, K.; Zhang, M.; Zhu, H.; Huang, M.; Zhu, Q.; Tang, D.; Han, X.; Li, J.; Sun, J.; Fu, J. Ascorbic acid alleviates damage from heat stress in the photosystem ii of tall fescue in both the photochemical and thermal phases. Front. Plant Sci. 2017, 8, 1373. [CrossRef] [PubMed]

139. Ergin, S.; Aydogan, C.; Ozturk, N.; Turhan, E. Effects of ascorbic acid application in strawberry plants during heat stress. Turk. J. Agric. Nat. Sci. 2014, 2, 1486-1491.

140. Liu, D.F.; Zhang, D.; Liu, G.Q.; Hussain, S.; Teng, Y.W. Influence of heat stress on leaf ultrastructure, photosynthetic performance, and ascorbate peroxidase gene expression of two pear cultivars (Pyrus pyrifolia). J. Zhejiang Univ. Sci. B 2013, 14, 1070-1083. [CrossRef]

141. Jin, S.H.; Li, X.Q.; Zheng, B.S.; Wang, J.G. Response of the Photosynthesis and Antioxidant Systems to High-Temperature Stress in Euonymus japonicus Seedlings. For. Sci. 2010, 56, 172-180. [CrossRef]

142. Manninen, S.; Huttunen, S.; Tømmervik, H.; Hole, L.R.; Solberg, S. Northern plants and ozone. AMBIO 2009, 38, 406-412. [CrossRef]

143. Crowther, T.W.; Glick, H.B.; Covey, K.R.; Bettigole, C.; Maynard, D.S.; Thomas, S.M.; Smith, J.R.; Hintler, G.; Duguid, M.C.; Amatulli, G.; et al. Mapping tree density at a global scale. Nature 2015, 525, 201-205. [CrossRef] 
144. Sen, A.; Khan, I.; Kundu, D.; Das, K.; Datta, J.K. Ecophysiological evaluation of tree species for biomonitoring of air quality and identification of air pollution-tolerant species. Environ. Monit. Assess. 2017, 189, 262. [CrossRef] [PubMed]

145. Skrynetska, I.; Karcz, J.; Barczyk, G.; Kandziora-Ciupa, M.; Ciepał, R.; Nadgórska-Socha, A. Using Plantago major and Plantago lanceolata in environmental pollution research in an urban area of Southern Poland. Environ. Sci. Poll. Res. 2019, 26, 23359-23371. [CrossRef] [PubMed]

146. Manjunath, B.T.; Reddy, J. Comparative evaluation of air pollution tolerance of plants from polluted and non-polluted regions of Bengaluru. J. Appl. Biol. Biotechnol. 2019, 7, 63-68. [CrossRef]

147. Nwazue, N.R. The Effect of Crude Oil Spill on the Ascorbic Acid Content of some selected vegetable species: Spinacea oleraceae, Solanum melongena and Talinum triangulare in an Oil polluted soil. Pak. J. Nutr. 2011, 10, 274-281. [CrossRef]

148. Grulke, N.E.; Heath, R.L. Ozone effects on plants in natural ecosystems. Plant Biol. 2019. [CrossRef]

149. Bellini, E.; De Tullio, M.C. Ascorbic Acid and Ozone: Novel Perspectives to Explain an Elusive Relationship. Plants 2019, 8, 122. [CrossRef]

150. Du, B.; Kreuzwieser, J.; Winkler, J.B.; Ghirardo, A.; Schnitzler, J.P.; Ache, P.; Alfarraj, S.; Hedrich, R.; White, P.; Rennenberg, H. Physiological responses of date palm (Phoenix dactylifera) seedlings to acute ozone exposure at high temperature. Environ. Pollut. 2018, 242, 905-913. [CrossRef]

151. Dusart, N.; Gérard, J.; Le Thiec, D.; Collignon, C.; Jolivet, Y.; Vaultier, M.N. Integrated analysis of the detoxification responses of two Euramerican poplar genotypes exposed to ozone and water deficit: Focus on the ascorbate-glutathione cycle. Sci. Tot. Environ. 2019, 651, 2365-2379. [CrossRef]

152. Gandin, A.; Davrinche, A.; Jolivet, Y. Deciphering the main determinants of $\mathrm{O}_{3}$ tolerance in Euramerican poplar genotypes. Sci. Tot. Environ. 2019, 656, 681-690. [CrossRef]

153. Zheng, Y.; Lyons, T.; Ollerenshaw, J.H.; Barnes, J.D. Ascorbate in the leaf apoplast is a factor mediating ozone resistance in Plantago major. Plant Physiol. Biochem. 2000, 38, 403-411. [CrossRef]

154. Robinson, J.M.; Britz, S.J. Tolerance of a field grown soybean cultivar to elevated ozone level is concurrent with higher leaflet ascorbic acid level, higher ascorbate-dehydroascorbate redox status, and long term photosynthetic productivity. Photosynth. Res. 2000, 64, 77-87. [CrossRef] [PubMed]

155. Feng, Z.; Pang, J.; Nouchi, I.; Kobayashi, K.; Yamakawa, T.; Zhu, J. Apoplastic ascorbate contributes to the differential ozone sensitivity in two varieties of winter wheat under fully open-air field conditions. Environ. Pollut. 2010, 158, 3539-3545. [CrossRef] [PubMed]

156. Matyssek, R.; Le Thiec, D.; Löw, M.; Dizengremel, P.; Nunn, A.J.; Häberle, K.H. Interactions between drought and $\mathrm{O}_{3}$ stress in forest trees. Plant Biol. 2006, 8, 11-17. [CrossRef] [PubMed]

157. Srivalli, B.; Sharma, G.; Khanna-Chopra, R. Antioxidative defense system in an upland rice cultivar subjected to increasing intensity of water stress followed by recovery. Physiol. Plant. 2003, 119, 503-512. [CrossRef]

158. Fox, H.; Doron-Faigenboim, A.; Kelly, G.; Bourstein, R.; Attia, Z.; Zhou, J.; Moshe, Y.; Moshelion, M.; David-Schwartz, R. Transcriptome analysis of Pinus halepensis under drought stress and during recovery. Tree Physiol. 2018, 38, 423-441. [CrossRef]

159. Seminario, A.; Song, L.; Zulet, A.; Nguyen, H.T.; González, E.M.; Larrainzar, E. Drought stress causes a reduction in the biosynthesis of ascorbic acid in soybean plants. Front. Plant Sci. 2017, 8, 1042. [CrossRef]

160. Hu, B.; Simon, J.; Rennenberg, H. Drought and air warming affect the species-specific levels of stress-related foliar metabolites of three oak species on acidic and calcareous soil. Tree Physiol. 2013, 33, 489-504. [CrossRef]

161. Aguiar-Silva, C.; Brandao, S.E.; Domingos, M.; Bulbovas, P. Antioxidant responses of Atlantic Forest native tree species as indicators of increasing tolerance to oxidative stress when they are exposed to air pollutants and seasonal tropical climate. Ecol. Ind. 2016, 63, 154-164. [CrossRef]

162. Du, B.; Jansen, K.; Kleiber, A.; Eiblmeier, M.; Kammerer, B.; Ensminger, I.; Gessler, A.; Rennenberg, H.; Kreuzwieser, J. A coastal and an interior Douglas fir provenance exhibit different metabolic strategies to deal with drought stress. Tree Physiol. 2016, 36, 148-163. [CrossRef]

163. Diaz-Vivancos, P.; Faize, L.; Nicolás, E.; Clemente-Moreno, M.J.; Bru-Martinez, R.; Burgos, L.; Hernández, J.A. Transformation of plum plants with a cytosolic ascorbate peroxidase transgene leads to enhanced water stress tolerance. Ann. Bot. 2016, 117, 1121-1131. [CrossRef]

164. Maruta, T.; Inoue, T.; Noshi, M.; Tamoi, M.; Yabuta, Y.; Yoshimura, K.; Ishikawa, T.; Shigeoka, S. Cytosolic ascorbate peroxidase 1 protects organelles against oxidative stress by wounding- and jasmonate-induced $\mathrm{H}_{2} \mathrm{O}_{2}$ in Arabidopsis plants. Biochim. Biophys. Acta 2012, 1820, 1901-1907. [CrossRef] [PubMed] 
165. Wang, Y.; Wisniewski, M.; Meilan, R.; Cui, M.; Webb, R.B.; Fuchigami, L.H. Overexpression of cytosolic ascorbate peroxidase in tomato confers tolerance to chilling and salt stress. J. Am. Soc. Hort. Sci. 2005, 130, 167-173. [CrossRef]

166. Duan, M.; Feng, H.L.; Wang, L.Y.; Li, D.; Meng, Q.W. Overexpression of thylakoidal ascorbate peroxidase shows enhanced resistance to chilling stress in tomato. J. Plant Physiol. 2012, 169, 867-877. [CrossRef] [PubMed]

167. Huang, C.; He, W.; Guo, J.; Chang, X.; Su, P.; Zhang, L. Increased sensitivity to salt stress in an ascorbate-deficient Arabidopsis mutant. J. Exp. Bot. 2005, 56, 3041-3049. [CrossRef] [PubMed]

168. Plesa, I.M.; González-Orenga, S.; Al Hassan, M.; Sestras, A.F.; Vicente, O.; Prohens, J.; Sestras, R.E.; Boscaiu, M. Effects of Drought and Salinity on European Larch (Larix decidua Mill.) Seedlings. Forests 2018, 9, 320. [CrossRef]

169. Le Martret, B.; Poage, M.; Shiel, K.; Nugent, G.D.; Dix, P.J. Tobacco chloroplast transformants expressing genes encoding dehydroascorbate reductase, glutathione reductase, and glutathione-S-transferase, exhibit altered anti-oxidant metabolism and improved abiotic stress tolerance. Plant Biotechnol. J. 2011, 9, 661-673. [CrossRef] [PubMed]

170. Akbari, M.; Mahna, N.; Ramesh, K.; Bandehagh, A.; Mazzuca, S. Ion homeostasis, osmoregulation, and physiological changes in the roots and leaves of pistachio rootstocks in response to salinity. Protoplasma 2018, 255, 1349-1362. [CrossRef]

171. Wang, Y.; Zhao, H.; Qin, H.; Li, Z.; Liu, H.; Wang, J.; Zhang, H.; Quan, R.; Huang, R.; Zhang, Z. The synthesis of ascorbic acid in rice roots plays an important role in the salt tolerance of Rice by scavenging ROS. Int. J. Mol. Sci. 2018, 19, 3347. [CrossRef]

172. Manikandan, M.; Kannan, V.; Mahalingam, K.; Vimala, A.; Chun, S. Phytoremediation potential of chromium-containing tannery effluent-contaminated soil by native Indian timber-yielding tree species. Prep. Biochem. Biotechnol. 2016, 46, 100-108. [CrossRef]

173. Michalec, K.; Barszcz, A.; Wasik, R. Influence of industrial pollution on the content of essential oils and vitamin C in twigs and needles of Scots pine. Sylwan 2015, 159, 516-522. [CrossRef]

174. Tran, T.H.; Mayzlish Gati, E.; Eshel, A.; Winters, G. Germination, physiological and biochemical responses of acacia seedlings (Acacia raddiana and Acacia tortilis) to petroleum contaminated soils. Environ. Pollut. 2018, 234, 642-655. [CrossRef] [PubMed]

175. Zemleduch-Barylska, A.; Lorenc-Plucińska, G. Response of leaf and fine roots proteomes of Salix viminalis L. to growth on Cr-rich tannery waste. Environ. Sci. Pollut. Res. 2016, 23, 18394-18406. [CrossRef] [PubMed]

176. Battke, F.; Ernst, D.; Halbach, S. Ascorbate promotes emission of mercury vapor from plants. Plant Cell Environ. 2005, 28, 1487-1495. [CrossRef]

177. Battke, F.; Ernst, D.; Fleischmann, F.; Halbach, S. Phytoreduction and volatilization of mercury by ascorbate in Arabidopsis thaliana, European beech and Norway spruce. Appl. Geochem. 2008, 23, 494-502. [CrossRef]

178. Mai, J.; Herbette, S.; Vandame, M.; Cavaloc, E.; Julien, J.L.; Ameglio, T.; Roeckel-Drevet, P. Contrasting strategies to cope with chilling stress among clones of a tropical tree, Hevea brasiliensis. Tree Physiol. 2010, 30, 1391-1402. [CrossRef] [PubMed]

179. Wang, J.X.; Li, Y.; Tian, W.M. Physiological Responses of Two Rubber Tree Clones with Differential Cold-Tolerant Potential to Cold Stress. J. Rubber Res. 2017, 20, 117-129. [CrossRef]

180. Pukacka, S.; Pukacki, P.M. Seasonal changes in antioxidant level of Scots pine (Pinus sylvestris L.) needles exposed to industrial pollution. I. Ascorbate and thiol content. Acta Physiol. Plant. 2000, 22, 451-456. [CrossRef]

181. Garcia-Plazaola, J.I.; Artetxe, U.; Becerril, J.M. Diurnal changes in antioxidant and carotenoid composition in the Mediterranean schlerophyll tree Quercus ilex (L.) during winter. Plant Sci. 1999, 143, 125-133. [CrossRef]

182. Han, Q.; Katahata, S.; Kakubari, Y.; Mukai, Y. Seasonal changes in the xanthophyll cycle and antioxidants in sun-exposed and shaded parts of the crown of Cryptomeria japonica in relation to rhodoxanthin accumulation during cold acclimation. Tree Physiol. 2004, 24, 609-616. [CrossRef]

183. Liu, T.W.; Wu, F.H.; Wang, W.H.; Chen, J.; Li, Z.J.; Dong, X.J.; Patton, J.; Pei, Z.M.; Zheng, H.L. Effects of calcium on seed germination, seedling growth and photosynthesis of six forest tree species under simulated acid rain. Tree Physiol. 2011, 31, 402-413. [CrossRef] 
184. Chen, J.; Wang, W.H.; Liu, T.W.; Wu, F.H.; Zheng, H.L. Photosynthetic and antioxidant responses of Liquidambar formosana and Schima superba seedlings to sulfuric-rich and nitric-rich simulated acid rain. Plant Physiol. Biochem. 2013, 64, 41-51. [CrossRef]

185. Kumari, P.; Tomar, Y.S. Effect of simulated acid rain on chlorophyll and ascorbic acid contents of Mentha piperita L. (Peppermint). Agric. Sci. Dig. 2009, 29, 1-6.

186. Salehi, M.; Fotouhi, G.; Jafarian, V. Evaluation of exogenous ascorbic acid application as a protective agent against simulated acid rain in Persian maple (Acer velutinum Boiss). Environ. Sci. Indian J. 2012, 7, 413-420.

187. Dempsey, R.W.; Merchant, A.; Tausz, M. Differences in ascorbate and glutathione levels as indicators of resistance and susceptibility in Eucalyptus trees infected with Phytophthora cinnamomi. Tree Physiol. 2012, 32, 1148-1160. [CrossRef]

188. Uzun, A.; Seday, U.; Canihos, E.; Gulsen, O. Oxidative enzyme responses of six citrus rootstocks infected with Phoma tracheiphila (petri) Kantschaveli and Gikashvili. Exp. Agric. 2012, 48, 563-572. [CrossRef]

189. Vrancken, K.; Schoofs, H.; Deckers, T.; Valcke, R. Real time qPCR expression analysis of some stress related genes in leaf tissue of Pyrus communis cv. Conference after infection with Erwinia amylovora. Trees 2012, 26, 67-73. [CrossRef]

190. Krajnc, A.U. A temporal analysis of antioxidative defense responses in the phloem of Picea abies after attack by Ips typographus. Tree Physiol. 2009, 29, 1059-1068. [CrossRef]

191. Barbehenn, R.V.; Jaros, A.; Yip, L.; Tran, L.; Kanellis, A.K.; Constabel, C.P. Evaluating Ascorbate Oxidase as a Plant Defense Against Leaf-Chewing Insects Using Transgenic Poplar. J. Chem. Ecol. 2008, 34, 1331-1340. [CrossRef]

192. Kovalikova, Z.; Kubes, J.; Skalicky, M.; Kuchtickova, N.; Maskova, L.; Tuma, J.; Vachova, P.; Hejnak, V. Changes in content of polyphenols and ascorbic acid in leaves of white cabbage after pest infestation. Molecules 2019, 24, 2622. [CrossRef]

193. Fujiwara, A.; Togawa, S.; Hikawa, T.; Matsuura, H.; Masuta, C.; Inukai, T. Ascorbic acid accumulates as a defense response to Turnip mosaic virus in resistant Brassica rapa cultivars. J. Exp. Bot. 2016, 67, 4391-4402. [CrossRef]

194. Pavet, V.; Olmos, E.; Kiddle, G.; Mowla, S.; Kumar, S.; Antoniw, J.; Alvarez, M.E.; Foyer, C.H. Ascorbic acid deficiency activates cell death and disease resistance responses in Arabidopsis. Plant Physiol. 2005, 139, 1291-1303. [CrossRef]

195. Botanga, C.J.; Bethke, G.; Chen, Z.; Gallie, D.R.; Fiehn, O.; Glazebrook, J. Metabolite profiling of Arabidopsis inoculated with Alternaria brassicicola reveals that ascorbate reduces disease severity. Mol. Plant Microbe Int. 2012, 25, 1628-1638. [CrossRef]

196. Blilou, I.; Bueno, P.; Ocampo, J.A.; García-Garrido, J.M. Induction of catalase and ascorbate peroxidase activities in tobacco roots inoculated with the arbuscular mycorrhizal Glomus mosseae. Mycol. Res. 2000, 104, 722-725. [CrossRef]

197. He, Z.; He, C.; Zhang, Z.; Zou, Z.; Wang, H. Changes of antioxidative enzymes and cell membrane osmosis in tomato colonized by arbuscular mycorrhizae under $\mathrm{NaCl}$ stress. Colloids Surf. B 2007, 59, 128-133. [CrossRef]

198. Alguacil, M.M.; Hernandez, J.A.; Caravaca, F.; Portillo, B.; Roldan, A. Antioxidant enzyme activities in shoots from three mycorrhizal shrub species afforested in a degraded semi-arid soil. Physiol. Plant. 2003, 118, 562-570. [CrossRef]

199. Wu, Q.S.; Xia, R.X.; Zou, Y.N. Reactive oxygen metabolism in mycorrhizal and non-mycorrhizal citrus (Poncirus trifoliata) seedlings subjected to water stress. J. Plant Physiol. 2006, 163, 1101-1110. [CrossRef]

200. Chen, M.; Arato, M.; Borghi, L.; Nouri, E.; Reinhardt, D. Beneficial Services of Arbuscular Mycorrhizal Fungi-From Ecology to Application. Front. Plant Sci. 2018, 9, 1270. [CrossRef]

201. Zhang, Y.; Han, L.; Ye, Z.; Li, H. Ascorbic acid accumulation is transcriptionally modulated in high-pigment-1 tomato fruit. Plant Mol. Biol. Rep. 2014, 32, 52-61. [CrossRef]

202. Buettner, K.M.; Collins, J.M.; Valentine, A.M. Titanium(IV) and vitamin C: Aqueous complexes of a bioactive form of Ti(IV). Inorg. Chem. 2012, 51, 11030-11039. [CrossRef]

203. Wojcik, P. Vigor and nutrition of apple trees in nursery as influenced by titanium sprays. J. Plant Nutr. 2002, 25, 1129-1138. [CrossRef]

204. Abdulrahman, A.S. Effect of Foliar Spray of Ascorbic Acid, Zinc, Seaweed Extracts and Biofertilizer (EM1) on Growth of Almonds (Prunus amygdalus) Seedling. Int. J. Pure Appl. Sci. 2013, 17, 62-71. 
205. Ibrahim, R.Z. Effect of foliar spray of ascorbic acid, Zn, seaweed extracts (sea) force and biofertilizers (EM-1) on vegetative growth and root growth of olive (Olea europaea L.) transplants cv. HojBlanca. Int. J. Pure Appl. Sci. Technol. 2013, 17, 79-89.

206. Penella, C.; Calatayud Á Melgar, J.C. Ascorbic Acid Alleviates Water Stress in Young Peach Trees and Improves Their Performance after Rewatering. Front. Plant Sci. 2017, 8, 1627. [CrossRef]

207. Noman, A.; Ali, S.; Naheed, F.; Ali, Q.; Farid, M.; Rizwan, M.; Irshad, M.K. Foliar application of ascorbate enhances the physiological and biochemical attributes of maize (Zea mays L.) cultivars under drought stress. Arch. Agron. Soil Sci. 2015, 61, 1659-1672. [CrossRef]

208. Hafez, E.M.; Gharib, H.S. Effect of exogenous application of ascorbic acid on physiological and biochemical characteristics of wheat under water stress. Int. J. Plant Prod. 2016, 10, 579-596.

209. Alamri, S.A.; Siddiqui, M.H.; Al-Khaishany, M.Y.Y.; Khan, M.N.; Ali, H.M.; Alaraidh, I.A.; Alsahli, A.A.; Al-Rabiah, H.; Mateen, M. Ascorbic acid improves the tolerance of wheat plants to lead toxicity. J. Plant Int. 2018, 13, 409-419. [CrossRef]

210. Yu, C.M.; Xie, F.D.; Ma, L.J. Effects of exogenous of ascorbic acid on genotoxicity of Pb in Vicia faba roots. Int. J. Agric. Biol. 2014, 16, 831-835.

211. Hemmati, K.; Ebadi, A.; Khomari, S.; Sedghi, M. Influence of ascorbic acid and 24-epibrassinolide on physiological characteristics of pot marigold under water-stress condition. J. Plant Interact. 2018, 13, 364-372. [CrossRef]

212. Shalata, A.; Neumann, P.M. Exogenous ascorbic acid (vitamin C) increases resistance to salt stress and reduces lipid peroxidation. J. Exp. Bot. 2001, 52, 2207-2211. [CrossRef]

213. Hussein, M.M.; Alva, A.K. Effects of zinc and ascorbic acid application on the growth and photosynthetic pigments of millet plants grown under different salinity. J. Agric. Sci. 2014, 5, 1253-1260. [CrossRef]

214. Azarpour, E.; Bozorgi, H.R.; Moraditochaee, M. Effects of Ascorbic Acid Foliar Spraying and Nitrogen Fertilizer Management in Spring Cultivation of Quinoa (Chenopodium quinoa) in North of Iran. Biol. Forum Int. J. 2014, 6, 254-260.

(C) 2019 by the authors. Licensee MDPI, Basel, Switzerland. This article is an open access article distributed under the terms and conditions of the Creative Commons Attribution (CC BY) license (http://creativecommons.org/licenses/by/4.0/). 